\title{
Assumptions of the Global Economic Crisis and Its Inception in the Spring of 2020 Due to the Covid-19 Pandemic
}

\author{
A.P. Portanskiy, Y.M. Sudakova, A.V. Larionov
}

Alexey P. Portanskiy - PhD, Professor, Department of World Economy, National Research University Higher School of Economics; 20 Myasnitskaya Ulitsa, Moscow, Russian Federation; E-mail: aportanskiy@hse.ru

Yulia M. Sudakova - PhD, Associate Professor, School of World Economy, National Research University Higher School of Economics; 20 Myasnitskaya Ulitsa, Moscow, Russian Federation; E-mail: ykukushkina@ hse.ru

Alexander V. Larionov - PhD, Doctor of Philosophy in Public Administration, Leading Researcher, Center for Strategic Forecasting and Planning, Institute of Economic Policy and Economic Security Problems, Financial University under the Government of the Russian Federation; 49 Leningradsky Prospekt, Moscow, 125993, Russian Federation; E-mail: alarionov@hse.ru

\begin{abstract}
Think tanks, as well as international organizations, have identified significant threats to the development of the world economy, increasing the likelihood of a new global financial crisis in late 2020 - early 2021. The main challenges to the system come from trade wars that could lead to a crisis in the international system of trade regulation, a decrease in the effectiveness of public policy instruments, and a deterioration in the dynamics of global economic growth. An important factor leading to a slowdown in the global economy in 2020 will also be the coronavirus pandemic, although it is difficult, in the first half of 2020, to assess its final impact. The combination of these negative factors, coupled with the unresolved problems of the 2008 global financial crisis, significantly increases the likelihood of a new global economic crisis which could surpass the Great Depression of the 1930s. This study systematizes the main forecasts by international organizations and analytical agencies for the growth of the world economy and considers various theoretical concepts to identify the symptoms of the impending crisis. Ultimately, this article offers options for reducing the negative impact of the crisis on Russia. In connection with the coronavirus pandemic, preliminary estimates have been made of the likely damage to the world economy and the prospects for its recovery.
\end{abstract}

Key words: Economic growth; global financial crisis; world economy; world trade; trade wars; theories of economic cycles

For citation: Portanskiy A., Sudakova Yu., Larionov A. (2020) Assumptions of the Global Economic Crisis and Its Inception in the Spring of 2020 Due to the COVID-19 Pandemic. International Organisations Research Journal, vol. 15, no 2, pp. 139-152 (in English). DOI: 10.17323/1996-7845-2020-02-09

\section{Introduction}

In recent years, the expert community has been actively discussing the likely beginning of the global economic crisis in 2020-21. Imbalances in the global economy increase the probability of a global crisis. These imbalances include the trade war between the U.S. and China, the increased level of protectionism, political and economic problems in the EU, in particular, 
related to Brexit, the slowdown in the Chinese economy. No one could say exactly where the "Black Swan" would come from. In late 2019 - early 2020, the concern of experts and the world community as a whole about climate change and environmental degradation has sharply increased. There was a strong belief that the failure to confront these problems would eventually trigger a global crisis.

However, these factors did not trigger the global crisis. Alarm signals from epidemiologists who warned of the threat of global pandemics after 2015 were almost ignored. As it turned out, the experts who warned about global pandemics were right. In the early spring of 2020, it became obvious that the cause of the new crisis is the coronavirus pandemic. The collapse in oil prices in March 2020 was an additional shock to the economies of many countries. Thus, the global economy was under a double blow. Published at the end of March 2020, forecasts suggested a serious reduction in global GDP by the end of 2020.

The expected fall in the economy in 2020 may be followed by a recession in 2021, and its consequences may be much more extensive and destructive than as a result of the global financial crisis in 2008. Many economists believe that the real causes of the 2008 crisis were not eliminated, and the countries' debt obligations were simply "flooded" with money.

The experience of global financial crises has shown that in each period there are some common symptoms indicating the beginning of a new crisis. In particular, on the U.S. stock exchanges in 2019, the yields of short-term securities were higher than the yields of bonds with longer maturities. The presence of such a symptom for a certain period of time, according to past experience, indicates the likelihood of a new global financial crisis.

Various indicators of the economic crisis reflect the growth of negative expectations on the part of investors, which lead to a sharp downturn of the market. Based on the analysis of theoretical works, it is possible to identify other signs indicating the possibility of the beginning of the world economic crisis. Increasing political divisions, along with growing imbalances in the global economy, can exacerbate the impact of negative factors increasing the risk of a new global crisis.

This paper examines the main indicators that reflect the probability of a new economic crisis. The indicators are based on existing theoretical concepts and patterns identified during various crises. The history of crises demonstrates the indicators that predict the beginning of a new global crisis. This research analyzes theoretical concepts and empirical data.

The study consists of three main parts. The first part considers the main forecasts of international organizations and analytical agencies on the state of the world economy. In the second part, we systematize the main indicators which are then correlated with real data. This predicts the beginning of a new economic crisis. The third part examines the first negative effects of the COVID-19 pandemic.

\section{The Pre-Coronavirus Forecasts of International Organizations and Analytical Agencies for Global Economic Growth in 2020}

The forecasts of international organizations and analytical agencies allows us to determine the main expectations of potential investors regarding the dynamics of the global economy in 2020 and beyond. Table 1 shows the forecasts of international organizations remained quite moderate in mid to late 2019, in terms of the growth of world GDP and world trade. All forecasts show the general growth of the global economy.

According to the IMF, in 2019 there will be a slowdown in global economic growth compared to 2018. Forecasts for different groups of countries are significantly different. The growth of the aggregate GDP of developed countries suggests a slowdown, while emerging economies, on aggregate, will increase the pace of economic growth compared to 2018. The IMF predicts that global economic growth of $3 \%$ will be the lowest since the global financial crisis of 
2008-09. Trade wars between the U.S. and China are a key reason for the slowdown in global economic growth. According to IMF forecasts, the growth in world trade will not exceed the growth in world GDP and will be approximately 3.2\% in 2020 [IMF, 2019].

Table 1. Systematization of Forecasts for the Development of the Global Economy

\begin{tabular}{|l|l|c|c|c|c|}
\hline \multirow{2}{*}{ Organization/Company } & \multirow{2}{*}{ Date of Publication } & \multicolumn{2}{c|}{$\begin{array}{c}\text { Predicted Growth } \\
\text { of World GDP, \% }\end{array}$} & \multicolumn{2}{c|}{$\begin{array}{c}\text { Predicted Growth } \\
\text { of World Trade, \% }\end{array}$} \\
\cline { 3 - 6 } & & $\mathbf{2 0 1 9}$ & $\mathbf{2 0 2 0}$ & $\mathbf{2 0 1 9}$ & $\mathbf{2 0 2 0}$ \\
\hline IMF & October 2019 & 3 & 3.4 & 1.1 & 3.2 \\
\hline World Bank & June 2019 & 2.6 & 2.7 & 1.5 & 2 \\
\hline WTO & October 2019 & 1.2 & 2.6 & 2.6 & 3 \\
\hline UNCTAD & July 2019 & 3 & 3.5 & 4 & 4,9 \\
\hline OECD & November 2019 & 2.91 & 2.94 & 1.2 & 1.6 \\
\hline Barclays & November 2019 & 3.1 & 3.2 & N/A & N/A \\
\hline Credit Suisse & November 2019 & 2.5 & 2.5 & N/A & N/A \\
\hline Goldman Sachs & November 2019 & 3.1 & 3.4 & N/A & N/A \\
\hline
\end{tabular}

Source: Compiled by the authors on the basis of official data of international organizations and companies [IMF, 2019; World Bank, 2019; WTO, 2019; UNCTAD, 2019; OECD, 2019; Barclays, 2019; Credit Suisse, 2019; Hatzius, Struyven, Walker, 2019].

The World Bank's (WB) estimates, see Table 1, confirm the IMF estimates [World Bank, 2020]. The WB forecast, in our opinion, deserves special attention. Based on an analysis of trends in the economies of several dozen countries, WB analysts concluded that the new economic crisis could surpass the crises of 1998 and 2008 with devastating consequences.

The WB saw the main problem as a sharp increase in the debt burden throughout the world, in both the private and public sectors. In 2018, global debt amounted to $230 \%$ of global GDP [Meredith, 2020]. The reason for the increase in global debt was unfulfilled obligations of developing countries. For the period 2010-18 the ratio of debt to GDP increased by more than 2 times [Kudenko, 2019].

Moreover, in the period from 2010-19. the emergence of debt was associated with the economic policy of China [Kudenko, 2019]. Over the years, the ratio of outstanding obligations to GDP reached $255 \%$. Their actual volume exceeded 20 trillion dollars. Recently, in the framework of the well-known China-2025 program, in order to gain access to the latest technology in the country, the mass purchase of Western companies was encouraged. This policy was ensured by providing opportunities to attract loans, which contributed to a significant increase in corporate debt. Debt growth was associated with the active development of shadow banking in China. By the end of 2019, the volume of shadow banking reached almost seven trillion dollars, in connection with which the IMF warned that this bubble could bring down the country's economy and launch a new Asian crisis, similar to the collapse of 1997-98 [Kudenko, 2019].

During 2019, the WTO lowered its forecast for world trade growth from $2.6 \%$ to $1.2 \%$ [WTO, 2019]. This decrease is also associated with trade wars and introduced by trade restrictions for certain groups of countries. The removal of these restrictions, and a focus on the priority of free trade, would have a positive impact on the growth of world trade, which would contribute to the growth of world GDP.

Uncertainty in trade, as a key negative factor, influencing global economic growth, is also highlighted by the United Nations Conference on Trade and Development (UNCTAD). 
Trade conflicts reduce opportunities for world trade, which leads to imbalances in the global economy. As a result, UNCTAD believes that world production will grow significantly faster than world trade [UNCTAD, 2019]. This trend contains a real risk of overproduction in some sectors, which could also lead to a new global crisis.

The OECD also updated its macroeconomic forecast downward during the year. The main reasons for the slowdown in economic growth in the world are the same: increasing protectionism and Brexit. The November OECD forecast for 2019 predicted a decline in the growth of global GDP to $2.9 \%$ in 2019 and 2020 [OECD, 2019]. The aggravation of trade wars has a significant negative impact on the expectations of business and investors. As a result, the growth rate of investments and the volume of world exports are reduced. A slowdown in world export growth was also observed before the start of the new global financial crisis in 2008.

In addition to the forecasts of global economic growth until 2020, made by international economic organizations, individual banks and analytical agencies offer their own forecasting options. According to their estimates, the situation may be slightly better than predicted by international organizations. For example, Barclays estimates the decline in economic growth rates to only $3.1-3.2 \%$ in $2019-20$, which is slightly lower than the growth rates observed over the past 20 years (the average value was $4.1 \%$ ). The trend does not necessarily indicate the start of a new global financial crisis [Barclays, 2019, p. 5].

Credit Suisse has approximately the same point of view: the global economy growth at $2.5 \%$ in 2019-20. This prediction is modest but suggests a recession is unlikely [Credit Suisse, 2019, p. 16].

According to Goldman Sachs, it is possible to expect a significant slowdown in global economic growth in 2020. However, Goldman Sachs predicts significant growth in the U.S. economy. It is expected that the global economy will accelerate in 2020, compared to 2019 [Hatzius, Struyven, Walker, 2019].

These expectations for 2020 are low and are associated with the significant fluctuations in world trade and investment. The intensification of trade wars will have a significant negative impact on the growth rate of the world economy, which could bring a new world economic crisis closer.

Since the beginning of a new crisis may be associated with economic imbalances, their identification is an important source of information about the state of the global economy. For the correct definition of crisis indicators, it is advisable to identify the growing imbalances at an early stage.

\section{The Indicators of the Beginning of a New Global Financial Crisis}

A global economic crisis is the result of growing imbalances in supply and demand and significant changes in investor expectations. The presence of such imbalances is evidenced by a number of indicators. It is advisable to analyze them, along with the analysis of various economic concepts, and to systematize the main phenomena, the occurrence of which reflects a high probability of a new economic crisis.

\section{Changes in the Yields of U.S. Bonds}

A key indicator of the beginning of a new global crisis is a change in the yields of shortterm and long-term bonds in the U.S. [Samiev, 2019]. Long-term bond yields should be higher so that investors can implement long-term projects. A situation where the yield of short-term bond yields exceeds the yield of long-term bonds over a long period of time has always been a symptom of an impending crisis. 
From the standpoint of economic theory and practice, the investor compares the expected returns of investments, including indicators of income and risk. Long-term investments are usually characterized by higher returns, however, the growth of uncertainty in the long run leads to expected returns growing in the short term. Due to significant fluctuations in the global economy, investors cannot forecast the profitability of their investments for long periods, and, therefore, the attractiveness of short-term investments increases. An increase in the duration of such a situation affects the behaviour of investors. They become more impatient, because, due to growing uncertainty, they cannot expect, with a sufficient degree of probability, to receive a higher income from investing in long-term securities. A paradoxical situation arises: short-term lending becomes more profitable than long-term periods. Thus, the excess of the yield of short securities, over long ones, can serve as an indicator of an approaching crisis.

If you look at the situation in the second half of 2019, then certain negative trends are obvious. On August 14, the yield on two-year bonds exceeded the yield on ten-year bonds by 1.2 basis points [RBC, 2019]. This indicated the likely start of a new global financial crisis. If you look at the latest available real data on the yield on U.S. government bonds, then there is a certain imbalance [Investing.com, n. d.]. The yield on annual U.S. bonds is lower than the yield on shorter-term bonds. In other words, certain distortions (imbalances) were observed in bond yields. This picture gives us reason to talk about worsening investor expectations.

\section{A Decrease in the Profitability of Logistics}

An important indicator of a decrease in business activity is a decrease in the profitability of operations related to transportation. The slowdown in the rate of economic interaction primarily affects companies engaged in organizing business interactions. The reduction in profits leads to a reduction in the entire sector, which affects the growth indicators of the entire economy.

A decline in demand for logistics services, which is a consequence of falling trade volumes and trade imbalances, can be considered as a pre-crisis indicator. A specific illustration of the significance of this indicator, can be considered the deterioration in the dynamics of FedEx shares at the end of 2019 [A2 Finance, n. d.]. The company has a wide client base but has shown a decrease in demand for its services and the ensuing decrease in profitability.

\section{The Problem of Limited Economic Instruments}

One possible symptom of economic turmoil is the weak performance of financial institutions. As Paul Krugman believes that the main problem is that we will not be able to come up with an effective response if the economy slows down. The region in which the crisis is most likely to occur is the Euro zone [Kto v Kurse, 2019].

The problem is that the reduction in opportunities to modernize public policy is associated with the relatively low indicators of economic policy, and in particular, with the key rates of central banks. If the key rate is high, a central bank may lower it in order to increase market activity. However, the possibility of using this tool is very limited in countries where the value of this rate is about $1 \%$, because there is simply nowhere to lower it further. Another tool may be to reduce collateral requirements and to extend credit terms, but this policy does not take into account possible risks and leads to the emergence of bubbles in the market.

It follows from the above that countries that have not exhausted the possibilities of state regulation of the economy are in a relatively better situation. The decline in the ability of the state to stimulate the economy, especially by means of monetary policy, can also serve as an indicator of a crisis. 
In recent years, a number of economies have been experiencing the problem of zero interest rates, which naturally has a negative impact on the ability of government policies to stimulate economic growth. The most important benchmark is the value of the key rate in the EU. In particular, the European Central Bank (ECB) continues to maintain negative interest rates on deposit operations (as of 18 September 2019 the interest rate was -0.5\%) [ECB, n. d.], see Table 2.

Table 2. Examples of Rates for Deposit and Credit Operations of the European Central Bank

\begin{tabular}{|l|c|c|}
\hline & Interest Rates for Deposits & Interest Rates for Credits (Marginal Lending Facility) \\
\hline 18 September 2019 & -0.50 & 0.25 \\
\hline 16 March 2016 & -0.40 & 0.25 \\
\hline 9 December 2015 & -0.30 & 0.3 \\
\hline 10 September 2014 & -0.20 & 0.3 \\
\hline 11 June 2014 & -0.10 & 0.4 \\
\hline 13 November 2013 & 0 & 0.75 \\
\hline 8 May 2013 & 0 & 1 \\
\hline 11 July 2012 & 0 & 1.5 \\
\hline 14 December 2011 & 0.25 & 1.75 \\
\hline
\end{tabular}

Source: Compiled by the authors based on data from [ECB, n. d.].

In the EU, there is a non-standard situation associated with the formation of negative interest rates for a long period of time. Negative interest rates demonstrate that the Central Bank is trying to minimize liquidity absorption operations by encouraging investment in the economy. Placing funds in the ECB at negative interest rates is not profitable, however, credit institutions still continue to use this mechanism. These trends in the monetary policy of the ECB demonstrate the likelihood of a decline in business activity in the EU.

\section{Theory of Tugan-Baranovsky}

Tugan-Baranovsky pointed out that the income received in the economy is distributed between consumption and saving [Tugan-Baranovsky, 1997]. Income directed to consumption is an incentive for producers to increase their output. Savings are directed to free capital and capital in industry. Capital in industry is investment in production, while free capital is placed using financial instruments. Free capital moves between different industries. In the case of capital accumulation in industry, its profitability decreases. A crisis occurs when the flow of free capital directed to industry runs out. The decrease in the amount of free capital is associated with a decrease in the profitability of its placement. This concept confirms the assumptions associated with changes in the yield of securities in the U.S. market. For the development of the real sector, it is necessary to obtain funds for a long period of time, however, it is difficult to attract such funds due to a decrease in the profitability over a long period of time.

\section{Cycles of Kondratiev}

Kondratiev developed a theoretical explanation for the dynamics of economic cycles [Kondratiev, 1989]. The cyclical nature of the economy depends on the level of technological development. The downward phase of the economic cycle is characterized by a depression in agriculture. Another of Kondratiev's empirical observations is related to the predominance of 
stages in the development of the crisis. If we consider large cycles, the period of upward phases is marked by years of recovery, while the period of downward phases of large cycles is marked by a depression in economic development. This makes it possible to single out the presence of certain crisis phenomena in the field of agriculture.

This indicator also finds confirmation, if you look at the data on the balance of supply and demand of agricultural products, it becomes obvious that there are certain imbalances. According to the OECD, in recent years there has been an excess of production growth over consumption, which has a negative impact on the price of agricultural products [OECD - FAO, 2019].

\section{Perez' Concept of Technological Revolutions}

Perez had a significant influence on the development of the concept of long waves [Perez, 2011]. Perez notes the crucial importance of technological revolutions and financial capital for economic development. The economy is constantly changing technological solutions which cause changes in the socio-economic organization. Changing technological paradigms is not possible without changes in governance, education, and regulation. Perez identifies the periodization of technological revolutions, the last occurred in 1971 with significant development of IT. It is possible to say that the global financial crisis of 2008 can be considered as a turning point in the economic life of countries. Since technological systems change every 50 years, the onset of the maturity phase should occur in 2020-21.

The maturity phase is characterized by:

- shortening the life cycle of emerging technologies. In the current period, we can observe a reduction in the periods of appearance of new high-tech products. Reducing the period of high profitability of products leads to a decrease in the profitability of their production; - increasing social tension. Rich people continue to make profits, but the poor lose income. This causes social tension in the society. These trends have been confirmed in recent years (for example, the "yellow vests" protest movement in France in 2019).

Reduced profits and increased social tension (which is likely to increase in the context of the coronavirus pandemic) will lead to the emergence of a crisis. Perez' concept is clearly confirmed by the periodization of crises presented in her research.

\section{Low Security of Credit Operations}

Minsky defined financial crises as the relationship between fluctuations in investment and the receipt of information [Minsky, 1986]. There are three categories of firms in the economy: stable firms, speculative firms, and Ponzi firms. Stable firms attract cash. They can pay both the loan body and its interest. Speculative firms accept credit and can pay back the loan body or the interest. Ponzi firms take out loans, but they cannot pay either the interest or the body of the loan. If they are unable to repay the money on the loans, they will refinance the loan. At the stage of recovery, this is quite easy to do, because lenders have low interest rates. The mechanism continues to work until there is some news that changes the expectations of creditors who increase interest rates. The result is the bankruptcy of Ponzi firms and some speculative firms. After the economy is compressed, the mechanism is repeated. An indicator of the crisis is excessive lending, which is not significantly secured.

If you look at the size of private debt-to-GDP ratios, then in France, Germany, the UK and the U.S., their value exceeds the actual size of GDP. A significant increase in private debt is observed in France in 2018 compared to 2013 (Fig. 1).

These trends show a significant increase in the probability of default, which may eventually lead to the instability associated with the growth of negative expectations of creditors. The 

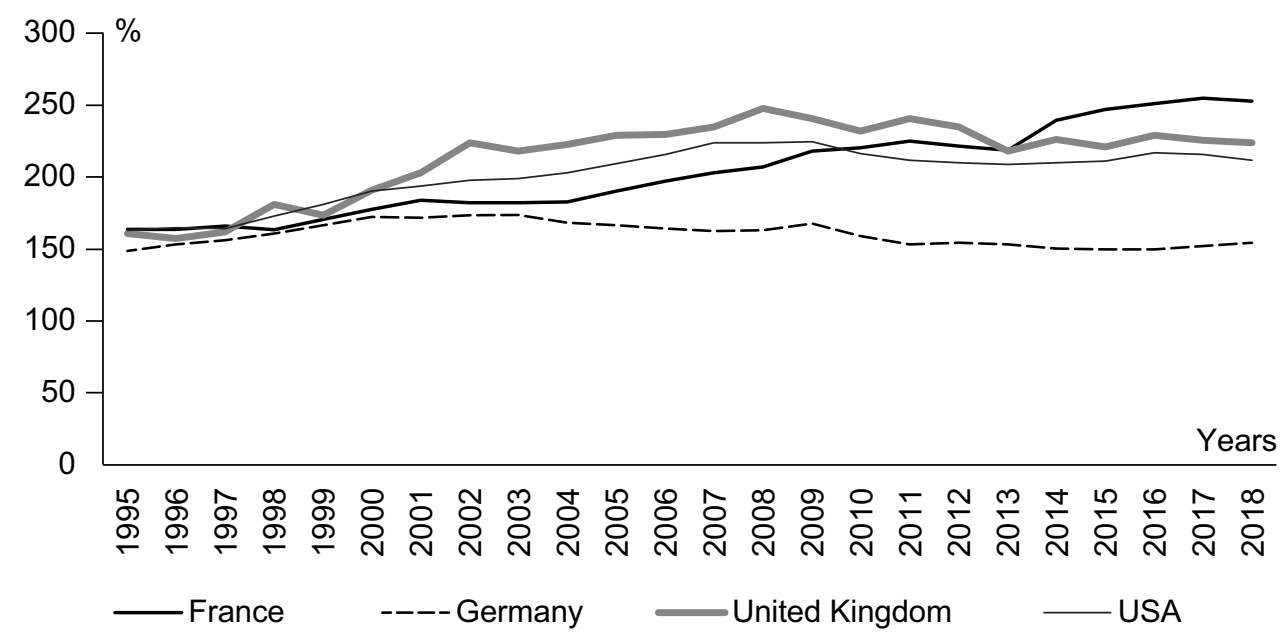

Fig. 1. Ratio of Private Debt to GDP, $\%$

Source: The authors based on [IMF, n. d.].

probability of default on loans may be a significant indicator which demonstrates the possibility of a new global financial crisis in 2020.

The analysis shows that at the beginning of 2020, most of the indicators of the likely onset of a new global economic crisis are present in the world economy. These indicators are systematized in Table 3.

The most significant negative impact is the lack of real tools to stabilize the situation in the event of a financial crisis. Central banks are not all able to properly stimulate economic activity by reducing key rates. In this regard, it is possible to expect an increase in the role of mandatory reserve requirements. An important factor in the policy is insufficient collateral to attract loans. Given this development, central banks will have to expand the use of unsecured loans (which may lead to additional risks) and specialized credit instruments.

Factors not considered in international forecasts for the beginning of 2020 may include the coronavirus epidemic, which is likely to have a significant negative impact on the world economy. Reducing the negative impact can be expected if an effective vaccine against the virus is created. However, it cannot be excluded that over the next $12-18$ months it will have a restraining effect on the state of the world economy.

Given the emergence of low interest rates in a number of countries and an increase in the number of deposits, there is sufficient free capital to ensure the growth of the world economy. In this regard, the lack of free capital cannot be considered as a source of the beginning of the global financial crisis. However, there may be a situation with the distribution of funds between speculative investments and investments in production. Potential crisis phenomena may be associated with changes in the expectations of economic agents regarding the prospects for economic growth. Examples of the implementation of negative expectations is the change in the yield of long-term and short-term securities and a decrease in the yields from logistics services, which can have a direct negative impact on business activity in the world economy.

For the first quarter of 2020, it cannot be said unequivocally that the onset of the global financial crisis is imminent. Obviously, investors have become more cautious [Kudenko, 2019].

Practically all well-known international agencies and authoritative experts predict the growth of the world economy in 2020 [MKRU, 2020]. At the same time, investor expectations and estimates remain quite cautious. Therefore, the possibility of a crisis cannot be excluded. Public 
Table 3. Indicators of the Beginning of a New Global Economic Crisis

\begin{tabular}{|l|l|l|}
\hline \multicolumn{1}{|c|}{ Indicator Name } & $\begin{array}{l}\text { Status at the Beginning } \\
\text { of } \mathbf{2 0 2 0}\end{array}$ & \multicolumn{1}{|c|}{ Brief Characteristic } \\
\hline $\begin{array}{l}\text { Changes in the yield of securities in } \\
\text { the United States }\end{array}$ & Occurs & $\begin{array}{l}\text { Short-term bond yields exceeded long-term bond yields } \\
\text { at the end of 2019 }\end{array}$ \\
\hline Coronavirus Pandemic & $\begin{array}{l}\text { At the beginning of 2020, the peak of the negative impact } \\
\text { of the coronavirus epidemic has not passed. It is possible } \\
\text { to expect a deterioration of the situation in terms of } \\
\text { reducing economic interaction with China }\end{array}$ \\
\hline $\begin{array}{l}\text { The decline of profitability in } \\
\text { logistics }\end{array}$ & Occurs & $\begin{array}{l}\text { For some product groups, there is a decrease in revenue } \\
\text { from transportation. The coronavirus epidemic in China } \\
\text { also has a negative impact on this process }\end{array}$ \\
\hline $\begin{array}{l}\text { The limitations of economic } \\
\text { instruments }\end{array}$ & $\begin{array}{l}\text { Some central banks have no real possibility of stimulating } \\
\text { the economy in the event of a global crisis (for example, } \\
\text { the ECB) }\end{array}$ \\
\hline $\begin{array}{l}\text { Reducing the availability of free } \\
\text { capital (the theory of Tugan- } \\
\text { Baranovsky) }\end{array}$ & Not observed & $\begin{array}{l}\text { Low interest rates and structural liquidity surpluses } \\
\text { demonstrate that there is sufficient free capital to invest }\end{array}$ \\
\hline $\begin{array}{l}\text { Imbalances in the development of } \\
\text { agriculture (cycles of Kondratiev) }\end{array}$ & Occurs & $\begin{array}{l}\text { In some areas of agriculture there is an appearance of } \\
\text { imbalances }\end{array}$ \\
\hline $\begin{array}{l}\text { Technological revolutions in the } \\
\text { concept of Perez }\end{array}$ & Occurs & $\begin{array}{l}\text { There is an increase in social tension and a decrease in } \\
\text { the life cycle of products created }\end{array}$ \\
\hline $\begin{array}{l}\text { Low security of credit operations } \\
\text { lending, which increases the likelihood of defaults }\end{array}$ \\
\hline
\end{tabular}

Source: Compiled by the authors.

policies of countries should include measures to prepare for such a turn of events. The latter is particularly relevant for export-oriented economies, such as Russia.

\section{Preliminary Estimates of the Impact of the Coronavirus Pandemic on the Global Economy}

By the beginning of the first quarter of 2020, the expert community did not yet have a clear opinion about the inevitability of the onset of the global economic crisis. A trigger that could bring down global markets was not yet visible. Many international agencies and reputable experts predicted global economic growth in 2020 [MKRU, 2020]. In turn, the World Bank, at the end of 2019, noted a significant increase in world debt, the total amount of which reached 246 trillion dollars. This fact had a negative impact on the expectations of investors, who, at the end of 2019, remained quite wary [Kudenko, 2019].

The beginning of the Covid-19 epidemic, in the first quarter of 2020, recognized by the World Health Organization (WHO) as a pandemic on March 11, was the trigger for the global crisis. Before the Covid-19 epidemic, WHO experts regularly spoke about the high probability of a pandemic at global level. The latter was associated with previous experience in controlling epidemics of SARS and MERS viruses, H1N1 swine flu, Ebola, etc. [Rodick, 2020]. However, the warnings of epidemiologists were virtually ignored.

As a result, even developed countries were not prepared for the pandemic, either in terms of sanitary and epidemiological, organizational and administrative, economic, or moral and political terms. An example of this is the United States, where the President, initially, strongly ruled out the spread of the epidemic in America, and a few weeks later, by the end of March, the country came out on top in the world rankings, in terms of the number of infected with corona- 
virus and was forced to start accepting foreign aid. The coming socio-economic consequences became clear: the number of applications for unemployment benefits jumped, in early April, to a historically record level - almost 17 million people lost their jobs in the United States in three weeks [Romashenko, 2020].

Delays in testing and the introduction of quarantine exacerbated the situation in the EU countries, in particular in Italy, Spain, France and the UK. The PMI business activity index in the Euro area showed a record decline for the month from 51.6 in February to 29.7 in March [Normand, 2020]. Other countries, such as Taiwan, South Korea, Singapore and Hong Kong, halted the spread of the disease at the beginning of April 2020. The latter was achieved through effective monitoring of infection chains, as well as the introduction and enforcement of strict quarantine measures [Rodrik, 2020].

In March - April 2020, the first estimates of the possible economic consequences of the pandemic were made. As noted by OECD Director General, Angel Gurria, at the G20 virtual summit in March 2020, each month of isolation will cost a reduction of two percentage points in annual economic growth in developed countries, which will ultimately negatively affect a third of their GDP [OECD, 2020].

The expectation of an unprecedented decline in world trade, in 2020, was warned by the World Trade Organization. According to forecasts of WTO experts, a decrease in the volume of trade in goods may reach $13 \%$ by the end of the year, according to an optimistic scenario. The pessimistic scenario, in case of failure in the fight against the epidemic, implies a decrease in trade by more than $32 \%$ [WTO, 2020b].

The wide variation between the two scenarios is primarily due to the very nature of the current health crisis and the significant uncertainty in the global economy in the near future. The uncertainty of the scenario estimates is also due to the fact that it is impossible to exclude the appearance of other factors that are unknown yet, the impact of which, on trade flows, will be significant. For example, conditions in the credit market may be complicated, which will inevitably narrow down the possibilities of financing trade. As a result, according to WTO estimates, the decline in exports will be more than $10 \%$ in almost all regions. The largest decline will be observed in exports from North America and Asia. Significant damage will be inflicted on industries with developed value chains. The latter will be especially noticeable in the export of electronics and automotive products. The pandemic necessitated the introduction of restrictions on movement between countries, which has a significant negative impact on trade in transport and tourism services [Portanskiy, 2020].

According to the head of the WTO, Roberto Azevedo, the crisis that began has a significant difference from the crisis of 2008 and, even, from the Great Depression of the 1930s. The banking system has a significant amount of free capital that can support the sustainable functioning of the global economy. Despite the growing concern of economists, before the pandemic, the world economy showed steady growth. It was a pandemic, as the WTO head put it, that "cut the fuel supply lines to the economic engine" [WTO, 2020a]. The international community is faced with the task of restoring the "fuel lines," which will enable us to move on to stabilizing the situation in the global economy. In order to realize an optimistic scenario, an effective government policy is needed to control the spread of the pandemic. It is also necessary to develop economic policy measures aimed at preserving jobs and business during a pandemic [Portanskiy, 2020]. Moreover, in no case should protectionist measures be introduced, leading to the emergence of new shocks for the global economy. It is through maintaining a policy of open markets that would help restore value chains, which would lead to the restoration of previous volumes of world trade and investment [WTO, 2020a].

By early April, developed countries had announced measures to support the economy in response to the pandemic. Thus, the EU finance ministers agreed on an anti-crisis plan to 
save the EU economy, according to which, a record amount of $€ 500$ billion will be allocated to stabilize the situation in the light of the coronavirus pandemic. Of these, $€ 300$ billion will go to support the unemployed, as well as small and medium-sized businesses [Gazeta.ru, 2020].

In the U.S., at the end of March, Congress adopted a package of economic measures worth $\$ 2.2$ trillion. In addition to this amount, a $\$ 350$ billion salary protection program should be adopted [Voice of America, 2020]. In general, in the United States, the declared assistance to support the economy, in connection with the pandemic by the beginning of April, amounted to about $12.5 \%$ of GDP. Germany allocated a third of national GDP to fight the pandemic. In Russia, at the beginning of April, 1.4 trillion roubles were allocated to counter the negative impacts of the pandemic, which amounted to 1.2\% of Russian GDP [Chevtaeva, 2020].

According to the data for April 2020, it should be noted that, in most countries, the tipping point that allows us to talk about reducing the negative impact of coronavirus on the economic life of countries has not been passed.

\section{Conclusion}

Given the rapidly changing circumstances in the world at the beginning of 2020, the authors feel justified to present the findings in two main parts: (1) the result of the study of the different approaches utilized, at the end of 2019, to predict the beginning of a new global financial crisis, and (2), analysis of the estimated impact of the pandemic in the industry and the prospects of overcoming it.

1) The study showed that, by the end of 2019, some economic indicators already predicted the onset of the global crisis, while others did not. From this picture, it follows that the beginning of the global financial crisis was possible, for example, if a major actor, such as Lehman Brothers, went bankrupt in 2008. In the absence of such an event, the world economy had a high chance of avoiding the onset of a new global crisis, especially since most well-known international agencies and authoritative experts predicted growth in 2020. Nevertheless, there was a premonition of a global crisis, as evidenced, for example, by the noticeable tension in the mood of investors. No one, however, dared to give an answer to the question of where the "Black Swan" would come from, i.e. what would trigger the crisis.

The conducted research gave some grounds to believe that, at the beginning of 2020, there was an increased probability of a new global economic crisis in 2020 - early 2021.

Given that the consequences of the previous global crisis, in 2008, were largely "flooded" with money, the new crisis is likely to reveal all the old problems. As a result, its negative impact may be stronger and more destructive than all previous crises in the twentieth and twenty-first centuries. The solution of crisis problems, by re-crediting the economy, is unlikely to lead to the desired result, since the leaders of world economic development are faced with the need to modernize the structure of national economies. The situation is aggravated by increased protectionism in the trade policy of the United States, primarily, which resulted in a trade standoff between the United States and a number of countries, primarily China. The continuation of the U.S. - China trade war, given the weight of these states in the world economy, poses a real threat to world trade and the global economy as a whole and remains the most important potential cause of the global crisis.

For Russia, early identification of signs of an approaching global crisis is extremely relevant due to the high dependence on external factors, which caused a severe recession in the country, reflecting the problems on world markets in 2008-09.

As for Russia's anti-crisis policy, it seems that it should include several main directions. In particular, it is necessary to continue forming funds that can be used to maintain the required 
level of public spending during the beginning of the crisis. The second important element is the implementation of state policy aimed at developing domestic competitive production. The latter involves redistributing part of government spending to certain industries. The choice of such industries is the task of a separate economic study.

2) The real trigger of the global crisis was the outbreak of a new coronavirus, recognized by WHO on 11 March 2020. The first weeks of the pandemic showed that, even developed countries, starting with the United States, were unprepared for it, either in terms of sanitary and epidemiological, organizational and administrative, economic, or moral and political terms. The corresponding warnings of epidemiologists about the real danger of a pandemic, made after 2015, were actually ignored. Some East Asian countries have responded better to the pandemic - South Korea, Singapore, and Hong Kong seem to have managed to control the spread of the disease by early April 2020.

The first analysis of the likely impact of the coronavirus pandemic on the global economy and trade, conducted, in particular, by the OECD and the WTO, provided rough estimates of the possible consequences of the disaster. According to the estimates received, the world economy and trade are expected to fall significantly by the end of 2020, both in the case of an optimistic scenario (up to 10\%) and in the case of a pessimistic scenario (about $30 \%$ or more). Considerable variation in numbers between scenarios is due, on the one hand, to the possibility of other, yet unknown factors with significant effects on production and trade, on the other hand, to the impossibility to assess the effectiveness of measures to combat the pandemic, to be taken by governments.

According to a number of authoritative sources, in particular the head of the WTO, Roberto Azevedo, the beginning of the crisis has significant differences from all previous ones, including the crisis of 2008 and the Great Depression of the 1930s by its very nature. The enforced isolation measures taken actually block a significant part of production and economic relations, both within and between states. Therefore, success in minimizing damage will be determined by the speed with which governments control the spread of the pandemic and the ability to choose the most rational future economic policies. The choice to introduce new protectionist barriers, under the guise of saving the national economy, which will eventually, inevitably, lead to new shocks for the economies, in addition to the existing ones, would be disastrous in the current circumstances. On the contrary, keeping markets open to international trade and investment would facilitate a faster recovery.

The crisis, associated with the new coronavirus pandemic, has caused a lot of assessments and opinions about the future of the global economy and the world as a whole, which can be divided into two groups: "the world will be different" and "the world will, basically, remain the same, where the existing trends will be consolidated." But both will tend to see the coronavirus disaster as a confirmation of their own point of view, looking for the first signs of the future economic and political order they have long desired!

Those who wanted to see the expanding role of the state will receive a lot of arguments to believe that this crisis justified their beliefs. There may be talk about the inefficiency of the current system of global regulation, caused by WHO mistakes in the fight against COVID-19. In turn, experts, criticizing the public administration system, will also talk about the insufficient level of its effectiveness. The latter will ask for a change in approaches to global regulation, demanding the creation of a unified world health system that will increase the effectiveness of counteraction to future pandemics. Thus, in a number of areas, there will be strengthening of public administration, with the simultaneous development of the globalization process [Rodrik, 2020]. Thus, COVID-19 is unlikely to significantly change the main trends in the development of the modern world, but it may well accelerate it. 


\section{References}

A2 Finance. (n. d.) FedEx Corp. Available at: https://a2-finance.com/ru/issuers/fedex-corp (accessed 17 February 2020) (in Russian).

Barclays. (2019) Outlook 2020. Available at: https://privatebank.barclays.com/news-and-insights/2019/november/outlook-2020/ (accessed 8 May 2012).

Chevtaeva I. (2020) Vlasti zarezervirovali 1,4 trln. rublej na bor'bu s koronavirusom [The Authorities Have Reserved 1.4 Trillion Roubles to Fight Against Coronavirus]. Vedomosti, 1 April. Available at: https://www.vedomosti.ru/economicBISs/articles/2020/04/01/826818-vlasti-zarezervirovali-14-trln (accessed 8 May 2020) (in Russian).

Credit Suisse. (2019) Investment Outlook 2020. Available at: file://D:/Downloads/investment-outlook2020-en.pdf (accessed 8 May 2020).

European Central Bank (ECB). (n. d.) Key Interest Rates. Available at: https://www.ecb.europa.eu/stats/policy_and_exchange_rates/key_ecb_interest_rates/html/index.en.html (accessed 17 February 2020).

Gazeta.ru. (2020) Shhit iz deneg: Evrogruppa soglasovala antikrizisnyj paket [Shield of Money: Eurogroup Agreed on an Anti-Crisis Package]. 10 April. Available at: https://www.gazeta.ru/politics/2020/04/10_a_13043401. shtml (accessed 10 April 2020) (in Russian).

Hatzius J., Struyven D., Walker R. (2019) A Break in the Clouds. Global Economics Analyst, Goldman Sachs Economic Research. Available at: https://www.goldmansachs.com/insights/pages/global-outlook-2020-f/report. pdf (accessed 8 May 2020).

International Monetary Fund (IMF). (2019) World Economic Outlook: Global Manufacturing Downturn, Rising Trade Barriers. World Economic Outlook Reports. Available at: https://www.imf.org/en/Publications/WEO/Issues/2019/10/01/world-economic-outlook-october-2019 (accessed 17 February 2020).

International Monetary Fund (IMF). (n. d.) Private Debt, All Instruments, \% of GDP. Available at: https://www. imf.org/external/datamapper/Privatedebt_all@GDD/USA/DEU/FRA/GBR (accessed 17 February 2020).

Investing.com. (n. d.) USA - Government Bonds. Available at: https://ru.investing.com/rates-bonds/usa-government-bonds (accessed 17 February 2020).

Kondratiev N.D. (1989) Bol'shie cikly jekonomicheskoj konjunktury: Doklad // Problemy jekonomicheskoj dinamiki [Large Cycles of Economic Conditions: Report: Problems of Economic Dynamics]. Moscow: Economics (in Russian).

Kto v Kurse. (2019) Pol Krugman: mirovoj krizis mozhet nastupit' uzhe v konce goda [Paul Krugman: The Global Crisis Could Come at the End of the Year]. 12 February. Available at: https://ktovkurse.com/mirovaya-ekonomika/pol-krugman-mirovoj-krizis-mozhet-nastupit-uzhe-v-kontse-goda (accessed 17 February 2020) (in Russian).

Kudenko A. (2019) Vsemirnyj bank zajavil o nachale novogo krizisa iz-za kitajcev [The World Bank Announced the Beginning of a New Crisis Over the Chinese]. RIA Novosti, 29 December. Available at: https://ria. $\mathrm{ru} / 20191229 / 1562884543 . \mathrm{html}$ (accessed 17 February 2020) (in Russian).

Meredith S. (2020) World Bank Warns of Global Debt Crisis Following the Fastest Increase in Borrowing Since the 1970s. CNBC, 9 January. Available at: https://www.cnbc.com/2020/01/09/economy-world-bankwarns-of-global-debt-crisis-as-borrowing-increases.html (accessed 17 February 2020).

Minsky P.H. (1986) Stabilizing an Unstable Economy. New Haven: Yale University Press.

MKRU. (2020) Jekonomist Sergej Guriev ocenil vozmozhnost' mirovogo krizisa 2020 [Economist Sergei Guriev Assessed the Possibility of a Global Crisis of 2020]. 1 January. Available at: https://www.mk.ru/economics/2020/01/01/ekonomist-sergey-guriev-ocenil-vozmozhnost-mirovogo-krizisa-2020.html (accessed 17 February 2020) (in Russian).

Normand G. (2020) En Europe, l'onde de choc du Covid-19 pourrait être dévastatrice [Covid-19 Shock Wave in Europe Could Be Devastating]. La Tribune, 3 April. Available at: https://www.latribune.fr/economie/union-europeenne/en-europe-1-onde-de-choc-du-covid-19-pourrait-etre-devastatrice-844286.html (accessed 10 April 2020) (in French). 
Organisation for Economic Co-operation and Development (OECD). (2019) Rethink Policy for a Changing World. OECD Economic Outlook, November. Available at: http://www.oecd.org/economic-outlook/november-2019/ (accessed 8 May 2020).

Organisation for Economic Co-operation and Development (OECD). (2020) OECD Updates G20 Summit on Outlook for Global Economy. 27 March. Available at: http://www.oecd.org/newsroom/oecd-updates-g20-summit-on-outlook-for-global-economy.htm (accessed 10 April 2020).

Organisation for Economic Co-operation and Development (OECD)-Food and Agriculture Organization (FAO). (2019) OECD-FAO Agricultural Outlook 2019-2028. Available at: http://www.fao.org/3/ca4076en/ ca4076en.pdf (accessed 8 May 2020).

Perez K. (2011) Tehnologicheskie revoljucii i finansovyj kapital. Dinamika puzyrej i periodov procvetanija [Technological Revolutions and Financial Capital: Bubble and Prosperity Dynamics]. Moscow: Publishing House "Delo" (in Russian).

Portanskiy A.P. (2020) Pandemija privedet k nebyvalomu padeniju mirovoj torgovli [A Pandemic Will Lead to an Unprecedented Drop in World Trade]. IMEMO, 10 April. Available at: https://www.imemo.ru/news/events/text/ pandemiya-privedet-k-nebivalomu-padeniyu-mirovoy-torgovli (accessed 10 April 2020) (in Russian).

RBC. (2019) Na rynke gosdolga SShA srabotal poslednij indikator budushhej recessii [On the US Government Debt Market, the Last Indicator of a Future Recession Has Triggered]. 14 April. Available at: https://www.rbc.ru/ economics/14/08/2019/5d53e34e9a79471e0a1a3ba5?utm_source=yxnews\&utm_medium=desktop\&utm_ referrer $=$ https\%3A\%2F\%2Fyandex.ru\%2Fnews (accessed 17 February 2020) (in Russian).

Rodrik D. (2020) Project Syndicate (SShA): Covid-19 radikal'no izmenit mir? [Project Syndicate (USA): Covid-19 Will Radically Change the World?]. Available at: https://inosmi.ru/politic/20200407/247214715.html (accessed 10 April 2020) (in Russian).

Romashenko S. (2020) V SShA zaregistrirovano eshhe 6,6 mln. bezrabotnyh [Another 6.6 Million New Unemployed Are Registered]. DW, 9 April. Available at: https://p.dw.com/p/3ahxK (accessed 10 April 2020) (in Russian).

Samiev P. (2019) Novye starye grabli: budet li v Rossii bankovskij krizis? [New Old Rake: Will There Be a Banking Crisis in Russia?] Forbes, 23 October. Available at: https://www.forbes.ru/finansy-i-investicii/385921novye-starye-grabli-budet-li-v-rossii-bankovskiy-krizis (accessed 17 February 2020) (in Russian).

Tugan-Baranovskij M.I. (1997) Periodicheskie promyshlennye krizisy [Periodic Industrial Crises] Moscow: Science (in Russian).

United Nations Conference on Trade and Development (UNCTAD). (2019) Mezhdunarodnaja torgovlja i razvitie. Doklad General'nogo sekretarja [International Trade and Development. Report of the Secretary-General]. Available at: https://unctad.org/meetings/en/SessionalDocuments/a74d221_ru.pdf (accessed 17 February 2020) (in Russian).

Voice of America. (2020) Kongressmeny toropjatsja utverdit' dopolnitel'noe finansirovanie dlja amerikanskih grazhdan [Congressmen Are in a Hurry to Approve Additional Funding for US Citizens]. 9 April. Available at: https://www.golos-ameriki.ru/a/lawmakers-race-approve-financing/5365355.html (accessed 10 April 2020) (in Russian).

World Bank. (2019) Global Economic Prospects. June 2019. Available at: https://openknowledge.worldbank. org/handle/10986/31655 (accessed 8 May 2020).

World Bank. (2020) Global Economic Prospects: Slow Growth, Policy Challenges. January. Available at: https:// www.worldbank.org/en/news/feature/2020/01/08/january-2020-global-economic-prospects-slow-growthpolicy-challenges (accessed 8 May 2020).

World Trade Organization (WTO). (2019) WTO Lowers Trade Forecast as Tensions Unsettle Global Economy. 840 Press Release, 1 October. Available at: https://www.wto.org/english/news_e/pres19_e/pr840_e.htm (accessed 17 February 2020).

World Trade Organization (WTO). (2020a) Remarks by DG Azevêdo. Speeches, 8 April. Available at: https:// www.wto.org/english/news_e/spra_e/spra303_e.htm (accessed 10 April 2020).

World Trade Organization (WTO). (2020b) Trade Set to Plunge as COVID-19 Pandemic Upends Global Economy. 855 Press Release, 8 April. Available at: https://www.wto.org/english/news_e/pres20_e/pr855_e.htm (accessed 10 April 2020). 


\title{
Trade Conflict Between the U.S. and China: What Are the Impacts on the Chinese Economy?
}

\author{
S. Park
}

Sang-Chul Park - Professor at Graduate School of Knowledge Based Technology and Energy, Korea Polytechnic University; 429-793, Kyonggi-Do, Siheung-City, 2121 Jeongwang-Dong, Korea; tel: +82 318041 0324 (O); E-mail: scpark@kpu.ac.kr

\begin{abstract}
A trade growth has slowed down in the global economy since the global financial crisis in 2008. It seemed to recover in 2017, but declined again since the Trump Administration in the USA posed trade protectionism in 2018 that led trade conflicts with its major trade partners such as Canada, China, Japan, Mexico, South Korea, the EU. Among these partners, the USA amended FTAs with Canada, Mexico, and South Korea by negotiations. It still negotiates FTA with Japan. However, the US government took a different approach to China in terms of tradethat is based on a hard line for setting high tariffs on Chinese import goods. China also responded with high tariffs on US import goods. As a result, the trade conflict started by criticizing each other, while the US represents its national interest first and China indicates the global free trade system as a key issue. In reality, the trade conflict has influenced not only the US and Chinese economy, but also the whole global economy negatively because the two economies as G2 accounted for nearly 40 percent of the global outcome. Therefore, it is one of the most sensitive issues on the global economic growth how it will affect to the global economy further. This paper argues why the trade conflict has emerged and how to solve it. It also focuses on economic impacts of the trade conflict on the global economy in general and Chinese economy in particular. Furthermore, it analyzes how the Chinese government deals with trade negotiations with the USA strategically.
\end{abstract}

Key words: trade protectionism; trade conflict; economic impacts; Chinese economy; world economy

For citation: Park S. (2020) Trade Conflict Between the U.S. and China: What Are the Impacts on the Chinese Economy? International Organisations Research Journal, vol. 15, no 2, pp. 153-168 (in English). DOI: 10.17323/19967845-2020-02-10

\section{Introduction}

The U.S. has been facing challenges due to the rise of China since China became the second largest economy in 2010. After the economic reform in 1978 named as the open policy, China's economic scale and foreign trade have been growing rapidly. As a result, Chinese economy surpassed German economy in 2009 and continuously Japanese economy in 2010 that was rather dramatic and very fast. China's role in the global economy has grown to be even more significant particularly since the global financial crisis (GFC) in 2008. It is widely recognized that the bilateral relationship between the U.S. and China will be a crucial determinant of the world's direction in the $21^{\text {st }}$ century because China has tried to build a new form of cooperative platform in world politics and global economy by creating G2 in 2013. Since then, the U.S. and China started to open G2 Summit annually under the Obama government, but it stopped in the Trump government [Hsieh, 2009; Kirton, 2013; Park, 2017].

In order to play its roles properly in the global economy, China requested for additional voting rights in the International Monetary Fund (IMF) in the G20 Summit in 2009that could increase its political and decision making power within the IMF. In 2016, the Chinese cur- 
rency, Yuan, officially joined the Special Drawing Rights (SDR) basket and became one of the foreign exchange reserve currencies of the IMF along with U.S. Dollar, British Pound, Euro, and Japanese Yen. Furthermore, the quota of China in the IMF increased 30.5 billion SDRs in 2017 that increased from 1.8 billion SDRs in 1980. As a result, its total vote share increased to 6.09 percent. The currency composition of the SDR basket is reviewed every five years, and the current weights for the component currencies are U.S. dollar (41.73 percent), Euro (30.93 percent), Chinese Yuan (10.92 percent), Japanese Yen (8.33 percent), and British Pound (8.09 percent) [Momani, 2016; IMF, 2015].

Although the Chinese voting rights in the IMF are still weaker than those of the U.S. and the EU, its economic power has already been the second largest economy in the world since 2010. With the high economic growth of 6.6 percent in 2018, not only the U.S., but also the EU officially announced China as an economic competitor in the pursuit of technological leadership and a systemic rival promoting an alternative model of governance. The EU urged that China is no longer regarded as a developing country, but a key global actor and leading technological power. Therefore, China should take more responsibilities for upholding the rules based on international order and greater reciprocity, non-discrimination, and openness of its system. For it, China publicly stated reform must be carried out into policies, and actions commensurate with its role and responsibility [European Commission, 2019].

With the rise of China as G2, it is significant to understand the bilateral trade relations between the U.S. and China and the impacts of the two nations' increasing interdependence on the global economy. Several negative perspectives on the trade conflicts between the U.S. and China had been already expressed in the mid of 2000s. The major reason for the proliferation of trade conflicts between the G2 was based on the U.S.'s large trade deficit with China that may lead to a trade war between the two nations. The terms of trade war refer to an economic conflict caused by the fact that one nation imposes trade restrictions against the other nation promoting to retaliate by imposing higher tariffs or non-tariff barriers. As a result, it leads to a deterioration of bilateral trade relations [Stewart, 2006; Bezlova, 2007; Hsieh, 2009; Park, 2017].

Such a trend has continued through all U.S. presidencies and led to protectionism since the Trump Administration. The U.S. and China realized the trade conflicts as trade war although the both parties are negotiating to solve the trade conflicts. China has noticed fundamental changes of the U.S. government on Chinese political and economic power. The U.S. considers China as a serious threat to the U.S. global interests. It also rules out the possibility of China reforming gradually towards the Western system that resulted in a comprehensive review of past decades' US policy towards China. Accordingly, the core reason of the trade conflicts between the two nations is not only because of the economy, but also due to the politics in order to gain the global hegemony. It means that escalation of conflicts and confrontation is inevitable for the two nations in the long term perspective [Chin et al., 2018].

This paper argues when and why the trade conflict between the U.S. and China started. It also analyzes what may be impacts of the trade conflict between the two nations on the global economy as a whole and on Chinese economy in particular as well as how to solve the trade friction. Furthermore, it suggests how to prevent the possible trade conflicts based on protectionism in the future. In order to find answers of these questions, critical analysis of literature, inference and cross sectional analysis based on statistical data are employed.

\section{Theoretical Debates}

Most of economists would agree with recent rebuttals to skepticism about the liberal trading order because of widely and rapidly spreading protectionism around the world. However, it is the fact that the intellectual and political support for free trade in the U.S. and elsewhere seems 
to have been weaken since the GFC in 2008. At the same time, protectionism has started since then although G20 member nations agreed to prevent it at the G20 Summit in Washington D.C. Therefore, free trade based on multilateralism is regarded as a wishful thinking for many countries particularly in the U.S. since the Trump Administration [Hufbauer, Schott, 2008].

Economic theory suggested comparative advantage and economies of scale would create economic gains through economic efficiency. Therefore, tariffs led to competitive tariff retaliation, which result in a massive shrinkage in foreign trade and low global economic growth. Economic theory never urged that free trade is good for all industries and all people. However, the winners from the free trade can afford to compensate the losers and every one could be made better off because the aggregate gains are positive [O'Rourke, Williamson, 2001; Rosen, 2008].

Economic theory also says that resources will flow to more efficient uses. However, it does not apply when governments and markets do not work well. Therefore, Samuelson already urged in 1972 that the aggregate gains from trade are not necessarily positive for all nations. He expanded his idea further to claim that growth in the rest of the world can damage a country if it takes place in sectors that compete with its native exports having comparative disadvantage. As a result, relative and even absolute a nation's GDP per capita can fall in such a condition. Gomory and Baumol extended Samuelson's theory and urged that there ismuch possible equilibrium with vastly different outcomes for the countries involved in a modern free trade world. They stated further that it is perfectly possible or rather common for a nation's equilibrium trade outcome to be less than the self-sufficiency outcome. Accordingly, good equilibrium is often created rather than bestowed by nature. As a result, countries can do much to affect their trading outcomes. Therefore, they urge US protectionism in trade [Samuelson, 2004; Gomory, Baumol, 2009].

However, Bhagwati criticizes that Samuelson's explanation cannot be used as a justification for US protectionism. He also denies Gomory and Baumol's argument because the U.S. could not carry out effective industrial policies to remedy it although their argument is true. Krugman and Obsfeld support Bhagwati's critics that it is an empirical question rather than a fact whether the growth of emerging economies has actually hurt advanced countries although theoretical possibility still exists [Bhagwati, 2009; Krugman, Obsfeld, 2009].

Economists have developed theoretical models for free trade and estimated welfare gains from reducing or eliminating trade barriers. In line with these models, Krugman, and Broda and Weinstein suggested that trade benefits society through gains overall quality and variety. However, this standard static growth from the free trade has left trade promoters quite vulnerable because the static growth models consider only the short run partial equilibrium efficiency gains. At the same time, the static models generate the gains from trade range very marginal [Krugman, 1997; Broda, Weinstein, 2006].

In order to deepen theoretical models finding long term efficiency gains and contribution of free trade to economic growth, economists have developed dynamic models estimating impacts of trade liberalization used by cross country regressions. By using these models, Bradford et al. urged that the US economy in 2005 could generate higher economic growth than without post war trade liberalization. However, Acemoglu left the issue of trade and growth undecided because there are models that highlight both positive and negative effects of trade on economic growth so that empirical work must be conducted. Accordingly, Lewer and Van den Berg pointed out that further development of dynamic models and additional empirical research are required. Additionally, linkages between trade and technology as well as trade and institutional quality must be further developed [Bradford et al., 2006; Acemoglu, 2009; Lewer, Van den Berg, 2007; Feenstra et al., 2009].

In this paper, the dynamic models rather than static models can be adopted because the former can explain the long term benefits of the free trade more precisely than the latter. Ac- 
cordingly, the conservative dualism of trade theory explains why the U.S. protectionism has emerged since the global financial crisis. It represents the Trump government trade policy than any other theoretical background. However, it has limited to generate the global economic growth sustainable. Therefore, it is possible that the dynamic models based on the long term efficiency gains and economic growth can correct the direction of protectionism toward the free trade. It is the reason why the U.S. and China have started the trade negotiation since 2018 and its outcome may be visible in the near future.

\section{Trade Conflicts Between the U.S. and China}

\section{Background}

The large size of the trade deficit between the U.S. and China has been a significant issue in bilateral trade relations. The Trump Administration regards the trade deficit with China as a sign of unfair economic policies in China although the U.S. government has suffered from its chronic budget deficit since the 1980s. Therefore, it has reportedly request China to develop a plan to reduce the bilateral trade deficit targeting by $\$ 100$ billion. However, there is a large difference between the two nations' view on their official trade statistics. According to the U.S. trade statistics in 2017, the merchandise trade deficit with China accounted for $\$ 375.3$ billion, while Chinese trade surplus with the U.S. in the same year was $\$ 275.8$ billion. Nearly $\$ 100$ billion difference exists between the two nations that could cause a serious dispute between the two parties. However, a statistical working group established by the U.S. - China Joint Commission on Commerce and Trade (JCCT) in 2004 identified the causes of the statistical discrepancies that does not mean any error in the official statistics of either country [Martin, 2018].

In fact, the U.S. has had the largest trade deficit in the world over three decades since the 1970s. Exceptionally, the U.S. had briefly a trade surplus in the mid of 1970s, but has experienced continuous deficit since then. The U.S. deficit increased over 5 percent of the national GDP in 2005 and fell to 2.9 percent of the national GDP in 2017. Owing to the rapidly increase of the U.S.'s aggregate trade deficit, the Trump government criticized major U.S. trade partners generally and China in particular. The U.S. argues that China must correct its unfair trade policies generating huge trade surpluses with the U.S. that creates the trade imbalances between the two nations [Genereux, 2017; WTO, 2018; Park, 2018].

\section{Development and Current Situation of Trade Conflicts}

After a longer than six decades' free trade movement, the U.S. has recently shaken the foundations of the global trading system by imposing steep tariffs on imports from China and other major trading partners since President Trump took the power in 2017. The trade conflicts between the U.S. and other major trading partners in general and China in particular started as the US International Trade Commission (USITC) found that imports of solar panels and washing machines caused injury to the US solar panel and washing machine industries in Oct. and Nov. 2017 respectively. The two U.S. industries filed separate requests for the investigations in early 2017 under Section 201 of the Trade Act of 1974 that were the first industry petitions since 2001.

As a result, President Trump approved global safeguard tariffs on $\$ 8.5$ billion in imports on solar cells and modules and $\$ 1.8$ billion of large residential washing machines in Jan. 2018 that were imposed beginning on $7 \mathrm{Feb}$. 2018. As a counter measure, the Chinese government requested to have consultations with the U.S. under the WTO dispute settlement framework concerning these imports. Moreover, the Chinese government announced preliminary antidumping duties of 
179.6 percent on imports of U.S. agricultural product, sorghum and imposed preliminary tariffs in April 2018. Chinese tariffs on US sorghum ended during negotiation in May 2018, and China also filed WTO dispute against U.S. solar panel tariffs in Aug. 2018. This signaled the significant trade conflict between the two parties that started the macroeconomic impact on the global economy negatively [Bown, Kolb, 2018; Ng, Chung, 2018; Bolt et al., 2019].

Moreover, the Trump Administration imposed tariffs on imports of steel with 25 percent and aluminum with 10 percent in Feb. 2018 under name of threatening the U.S. national security based on Section 232 of the Trade Expansion Act of 1962. Chinese portion covered only 6 percent of imports due to prior US imposition of antidumping and countervailing duties. Therefore, the Chinese retaliatory tariffs on this issue only accounted for $\$ 3$ billion. China also imposed tariffs on various imports from the U.S. that included 128 tariff lines.

In addition to steel and aluminum, President Trump imposed 25 percent tariffs on 1,333 Chinese products in two phases starting July 2018 that accounted for $\$ 50$ billion targeted intermediate inputs and capital products because U.S. Trade Representative (USTR) found that China conducted unfair trade practices related to technology transfer, intellectual property, and innovation that was investigated under Section 301 of the Trade Act of 1974. China also issued an updated $\$ 50$ billion retaliation list of 25 percent tariffs including agricultural and food products, crude oil, automobiles, airplanes, chemical products, medical equipment and energy products etc. in two phases that accounted for 659 tariff lines. Since then, trade conflicts between the two parties have continued, and President Trump directed the USTR to identify an additional \$200 billion of Chinese imports for additional tariffs of 10 percent in response of Chinese retaliatory tariffs in June 2018. The USTR finalized the tariff list containing 5,745 full or partial lines of the original 6,031 tariff lines that were on a proposed list of Chinese imports. The additional tariff was effective starting in Sep. 2018 [Bown, Kolb, 2018; McLarty Associates, 2018; Ng, Chung, 2018; USTR, 2018].

Since the additional tariff of 10 percent on $\$ 200$ billion of Chinese imports, the ongoing trade conflict between the two nations has continued. Amid the trade conflict, the U.S. government threatened to impose tariffs as high as 25 percent on all U.S imports from China if China implements its further retaliation measures. President Trump decided on increasing the tariffs to 25 percent on $\$ 200$ billion of Chinese imports in May as the trade negotiation between the two nations was not met. As a result, China also responded its retaliation measure to set the high tariff up to 25 percent on $\$ 60$ billion of U.S. imports. Due to the ongoing trade conflict, the neighboring countries of China such as Japan, South Korea, Thailand, and Vietnam suffer from a stiff decline of their exports to China although their exports to the U.S. increases at the same time. Additionally, China started to consider all options to strike back by targeting large-sized US corporations operating in China. It was announced after the U.S. government prepared more tariffs on imports of China and banned Chinese high-tech firm, Huawei [Bolt et al., 2019; Strauss, 2019; Cong, 2019].

During the trade conflict, the U.S. government has considered to raise the tariffs on all imports of automobiles and auto parts that could impact on the global economy massively. It could raise the risk of spreading the trade conflict at a global scale and escalating retaliation measures all over the world. However, the Trump Administration announced a delay of its final decision on whether to impose broad tariffs on automobile and auto part imports for about six months right after imposing the tariff of 25 percent on $\$ 200$ billion of Chinese imports. If the tariffs on all imports of automobiles and auto parts are realized, the U.S. major trade partners such as Germany, Japan, South Korea, China, Mexico etc. will be affected severely that could result in a global economic slowdown. In fact, the global trade conflict started due to the high U.S. trade deficit from China and other major trade partners. However, at the same time, the U.S. high tariffs imposing against the U.S. major trade partners in general and China in particular have intensified the global trade conflict further [Salama, Mauldin, 2019, table 1]. 
Despite the harsh trade conflicts, the two largest economies finally agreed the trade deal in Dec. 2019 and signed on it in Jan. 2020. It could change the economic relationship between the U.S. and China significantly. The agreement includes that China has committed to buy an additional $\$ 200$ billion of the U.S. goods and services by 2021 and ban on illegal business practices that the U.S. government has criticized. However, the accord does not provide information about how to work in practices. Therefore, it is possible that China could interpret text of the accord differently than the U.S. It is the reason why the second trade war between the two parties may be possible in the future [Eavis et al., 2020; Office of the United States Trade Representative \& Department of Treasury, 2020].

Table 1. Category and Content of US Trade Conflicts With Major Trading Partners

\begin{tabular}{|l|l|}
\hline \multicolumn{1}{|c|}{ Category } & \multicolumn{1}{c|}{ Content } \\
\hline Solar Panels and Washing Machine & $\begin{array}{l}\text { Imposing safeguard tariffs on \$8.5 billion in solar panels and \$1.8 billion in } \\
\text { washing machines. } \\
\text { Chinese preliminary tariffs on US sorghum \& filing WTO dispute against US } \\
\text { solar panels tariffs. } \\
\text { Korean filing WTO dispute against US solar panels and washing machines } \\
\text { tariffs }\end{array}$ \\
\hline $\begin{array}{l}\text { Steel and aluminum as national security } \\
\text { threat }\end{array}$ & $\begin{array}{l}\text { Section 232 of Trade Expansion Act of 1962. } \\
\text { 25 percent on steel \& 10 percent on aluminum covering \$48 billion of imports }\end{array}$ \\
\hline $\begin{array}{l}\text { Unfair trade practices for technology } \\
\text { \&intellectual property (IP) }\end{array}$ & $\begin{array}{l}\text { Section 301 of Trade Act of 1974. } \\
\text { \$50 billion of 1,333 Chinese products for 25 percent tariffs with two phases. } \\
\text { Identifying \$200 billion for 10 percent tariffs in Sep. 2018. } \\
\text { Raising tariff to 25 percent on \$200 billion in May 2019 }\end{array}$ \\
\hline Auto vehicles as national security threat & $\begin{array}{l}\text { Announcing to raise tariffs up to 25 percent and delay six months in 2019 } \\
\text { mainly against the EU, Japan and South Korea }\end{array}$ \\
\hline
\end{tabular}

Source: [Bown, Kolb, 2018; McLarty Associates, 2018; Ng, Chung, 2018; USTR, 2018; Salama, Mauldin, 2019; Strauss, 2019].

\section{Reasons for the Trade Conflict Between the U.S. and China}

There are many reasons for trade conflicts whenever these take place regardless of between nations and regions. Among these, the trade conflict between the two largest economies can be explained with the following four reasons that are claimed by the two parties commonly and observed by the outsiders. These are trade imbalance between the two nations, US protectionism based on income inequality and chronic budget deficit, China's unfair trade against intellectual property right (IPR), technology transfer and innovation for US companies, and competition of hegemony power in the $21^{\text {st }}$ century.

Firstly, the U.S. trade deficit with China accounted for \$419 billion in 2018 that increased from \$376 billion in 2017 although the Trump Administration imposed high tariffs on imports goods from China. The share of U.S. trade deficit with China in 2018 accounted for nearly 42 percent of the total U.S. trade deficit although it declined from 49 percent in 2015. The U.S. imported $\$ 540$ billion from China in 2018, while it exported $\$ 120$ billion to China in the same year. The three biggest categories of the U.S. imports from China were computers and accessories, cell phones, and apparel and footwear that accounted for $\$ 77$ billion, $\$ 70$ billion, and $\$ 54$ billion respectively. The three largest US exports to China were commercial aircraft, soybeans, and autos that accounted for $\$ 16$ billion, $\$ 12$ billion and $\$ 10$ billion respectively. It indicates that the U.S. trade deficit with China is not a short term based phenomena, but a long term based chronic trend due to the different industrial structures between the two nations. As a 
result, the U.S. trade deficit increased from $\$ 273$ billion in 2010 to $\$ 419$ billion in 2018 continuously [Amadeo, 2019; Park, 2018; United States Census Bureau, 2019, fig. 1].

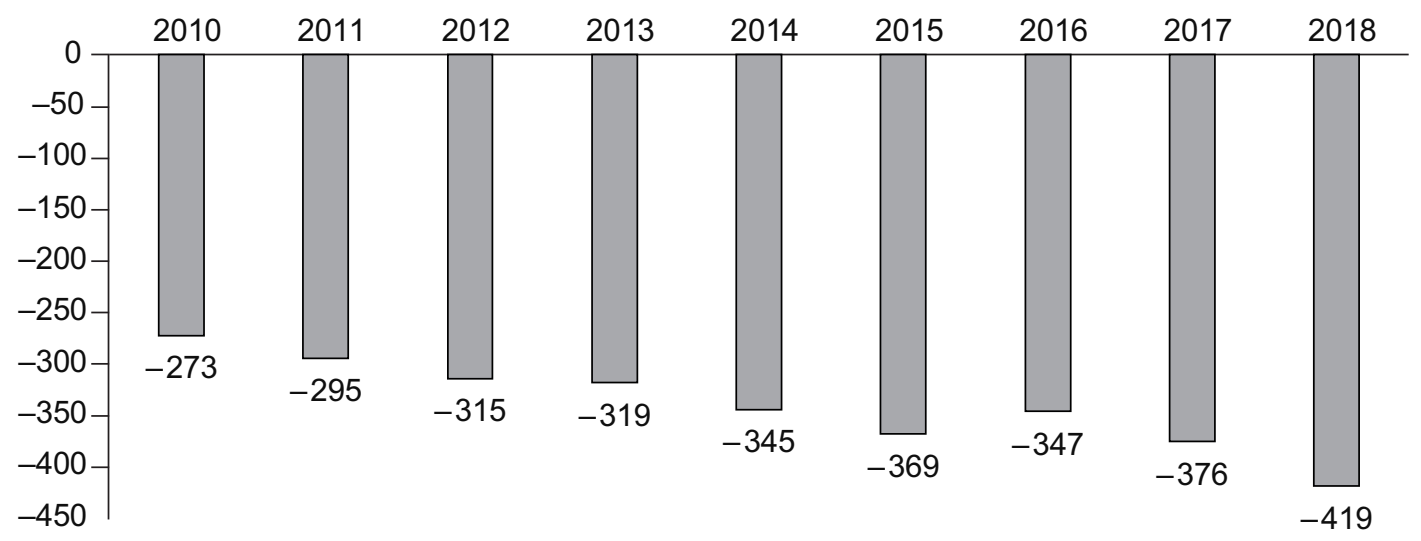

Trade deficit

Fig. 1. The U.S. Trade Deficit with China from 2010 to 2018 (As of USD billion)

Source: [United States Census Bureau, 2019].

Secondly, the U.S. as the largest economy in the world has led to protectionism since the GFC in general and the Trump Administration in particular that has affected to the global economy severely. The U.S. protectionism impacts on the global economy negatively due to its economic size compared with other economies. It results mainly from the income inequality and distribution as well as a vast government budget deficit in the U.S. that has risen since the 2000s. However, economists are not sure yet whether the free trade has created the income inequality and the budget deficit or not. Some economists urged that the free trade affected only about 20 percent of increase in inequality in the 1970s and 1980s when the U.S. trade was mostly North to North. With the shift of trade relations to North to South, a more negative impact on the wage of low skilled workers in the U.S. took place since the 1990s. Whatever the cause of rise in inequality, the fact is that the average of real wage of production per hour has been stagnant since the 1980s. As a result, the wage increase in production has lagged behind the growth in real GDP per capita. Moreover, the share of pre-tax income in the top one percent increased from 10.5 percent in 1980 to over 20 percent in 2016, while its share of bottom 50 percent declined from 20.5 percent to 13 percent during the same period. It may have caused a lower tax revenue. As a result, it led the U.S. as the most inequality nation among the advanced countries based on Gini index that increased up to 0.41 in 2016 [Krugman, 2009; ERP, 2009; Hillebrand et al., 2010; OECD, 2014; Piketty, 2014; Alvaredo et al., 2017; World Bank, 2019, fig. 2].

Thirdly, President Trump asked US Trade Representative (USTR) to investigate whether Chinese laws, policies, practices that may harm US intellectual property rights, innovation or technology development in Aug. 2017 or not, and the USTR initiated investigation of China under Section 301 of the Trade Act of 1974. It found that China conducted unfair trade practices related to technology transfer, intellectual property, and innovation so that President Trump imposed 25 percent tariffs on 1,333 Chinese products in two phases starting July 2018 that accounted for $\$ 50$ billion targeted intermediate inputs and capital products. China also retaliated with an updated $\$ 50$ billion list of 25 percent tariffs including agricultural and food products, 
crude oil, automobiles, airplanes, chemical products, medical equipment and energy products etc. in two phases that accounted for 659 tariff lines [Ng, Chung, 2018; USTR, 2018].

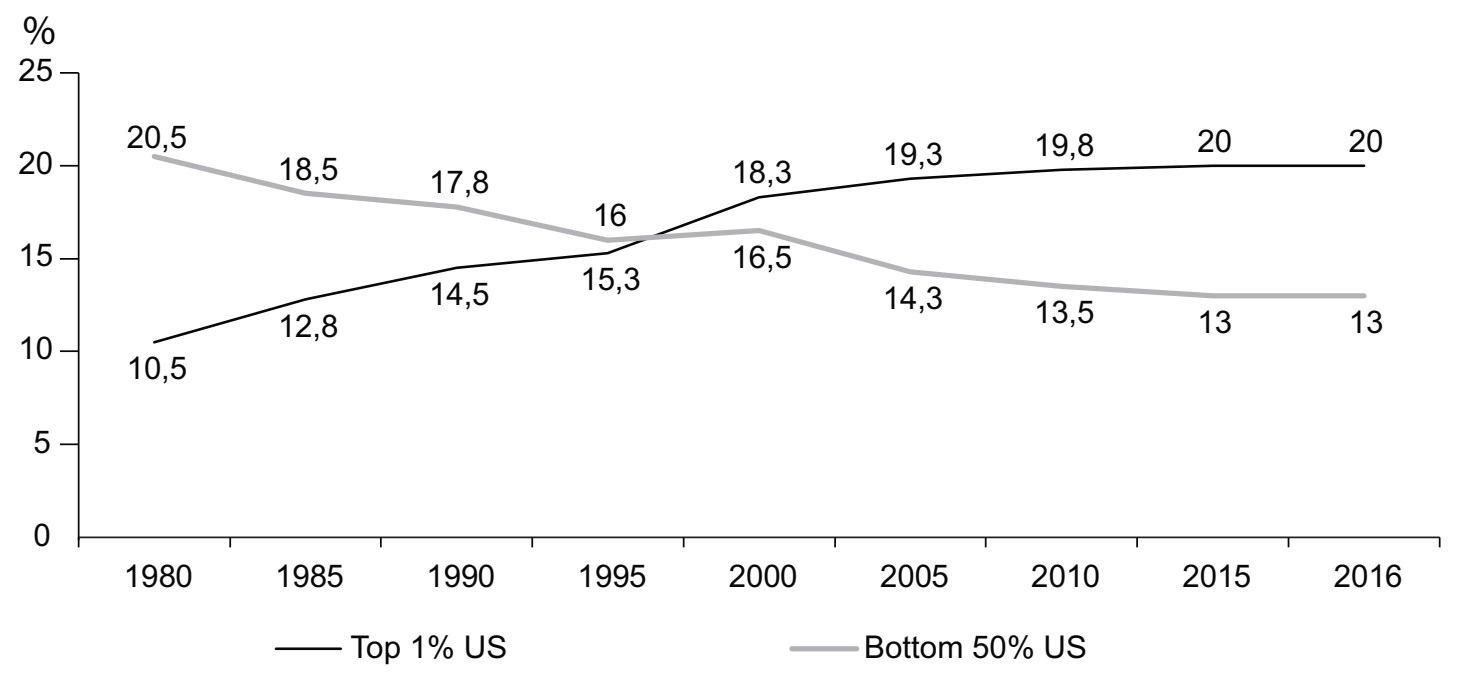

Fig. 2. Share of Pre Tax Income in the U.S. (As of 1980-2016)

Source: [Alvaredo et al., 2017].

Last, but not least the U.S. - China trade conflict is based on the competition of a hegemony power in the $21^{\text {st }}$ century. Therefore, several scholars expect that it would take a long term instead of a short term. In the national security strategy report in 2017, the U.S. called China as its strategic rival. Additionally, the U.S. government particularly concerned the Chinese national development strategy, the Made in China 2025 program as a national threat in terms of high tech development that plays the core role in strengthening Chinese future competitiveness. In line with such a strategic point of view on the high tech area, President Trump signed on the executive order to ban the Chinese high tech firm, Huawei in May 2019 that is one of the leading global telecommunication companies in 5G technology in the world along with Ericsson, Nokia, and Samsung Electronics. The 5G technology is the key technology to realize the Fourth Industrial Revolution connecting the physical and cyber world. At present, China is one of the leading countries in this field ahead the U.S. that the U.S. government concerns mostly. If China succeeds the Fourth Industrial Revolution based on the $5 \mathrm{G}$ technologies, the U.S. technological supremacy will be over, and China will be the game changer in the world. Therefore, the key issue on the trade conflict between the two parties is rather politics than economics that escalate confrontation between the two nations continuously in the future [Schwab, 2016; The White House, 2017; Chin et al., 2018; Jiming, 2018; Doffman, 2019].

\section{Analysis on Impacts of the Trade Conflict}

\section{Trade Conflict and Tariff Measures}

Impacts of the trade conflict are not only bilateral, but also global. Particularly, the two largest economies in the world generate two fifths of global GDP and about a quarter of global trade. Therefore, the bilateral trade conflict between the U.S. and China is worrisome for both 
the region and the world because the two nations are two of the three main hubs for global production chains along with the European Union (EU) with tight trade links in key industrial sectors such as electronics and high technology equipment [Abiad et al., 2018].

Most of the products affected in the first two rounds of bilateral tariffs imposed on imports of Chinese goods for $\$ 50$ billion are mainly capital and intermediate goods that are targeted for the Made in China 2025 plan. In order to meet the target of the plan, China needs to import high tech products for its end-products. These products are deeply connected with global value chains. By contrary, China retaliated to impose tariffs mostly on imports of the U.S. agricultural products, chemicals, medical and energy equipment. These products are rather homogeneous goods available in the global markets.

The second round of the trade conflict of $\$ 200$ billion by the U.S. and $\$ 60$ billion tariffs by China started in the mid of 2018 that affected to consumer goods because fewer supply chain lines were left to set the targets. The trade tension between the two nations escalated continuously, and the U.S. threatened to impose tariffs of another $\$ 267$ billion on Chinese imports. It was all goods imported from China in 2018. China also threatened to retaliate with similar tariffs on all imports from the U.S. It also considers other measures to retaliate the U.S. companies operating in China. In the global trade tension, the U.S. government has considered to set the tariff of 25 percent on imports of automobiles and auto parts from all trading partners that would affect $\$ 350$ billion worth of goods [Abiad et al., 2018; Park, 2018].

\section{Impacts on the U.S. and Chinese Economy}

The escalation of trade conflict and threats between the two nations caused a significant pressure of outlook for the global economic growth in general and the Chinese economy in particular. The Chinese export and sales started already weak in the third quarter of 2018. Additionally, the threats influenced investors in a wait and see mode and accelerated restrictions of foreign direct investment (FDI) for the high tech areas from China and vice versa [Hanemann, 2018].

In order to analyze impacts of the trade conflict on the two economies, it is reasonable to adopt studies of global research institutes providing objective and independent analyses, which are not influenced by the U.S. and China. One of these is the report of Asian Development Bank (ADB) that analyzes the implications of three scenarios. The first scenario is a current scenario including all trade measures implemented as of Oct. 2018 with $\$ 200$ billion of imports from China in 25 percent of tariffs. The second one is a bilateral escalation scenario intensifying to impose blanket tariffs of 25 percent on all merchandise imports from the both countries. Finally, the last scenario is a worst case scenario including measures under the bilateral escalation scenario and a global escalation of trade conflict between the U.S. and other trading partners in automobiles and parts imposed by the U.S. on 25 percent tariffs of imports from other nations (see table 2).

The immediate impact of these three scenarios will take time to be materialized fully. The current scenario will be affected fully in 2019, while the direct impact of the worst scenario will approach nearly a full effect in 2020 . The worst scenario could be completed in 2021 if the trade deal between the two economies could not be made successfully. Moreover, the scenario modeling is used by the ADB Multiregional Input-Output Table (ADB MRIOT) for the year 2017 in order to quantify the impact of changes in tariffs working through local and production chains that provides advantages in individual economies and sectors as well as understanding the structure and evolution of global value chains. The direct impact of the trade conflict 
is quantified at product level gathered by published lists of tariff affected commodities for all countries involved in the trade conflicts as of Sep. 2018. Additionally, these commodities are matched with detailed trade data from BACI and the United States Census Bureau in 2017 that uses a 6- to 10-digit Harmonized System classification [Abiad et al., 2018; Wang et al., 2018].

Table 2. Description and Size of Three Modeled Scenarios Between the U.S. and China

\begin{tabular}{|c|c|c|c|}
\hline Scenarios & US Tariff Actions and Size of Impact & Retaliatory Measures by China & Date of Implementation \\
\hline \multirow[t]{4}{*}{$\begin{array}{l}\text { Current Scenario } \\
\text { (measures } \\
\text { implemented as of } \\
\text { Oct. 2018) }\end{array}$} & $\begin{array}{l}30 \% \text { and } 20 \% \text { blanket tariffs on all } \\
\text { imports of solar panels and wash } \\
\text { machines worth } \$ 10.3 \text { billion ( } 0.4 \% \\
\text { of US imports) }\end{array}$ & $\begin{array}{l}\text { China imposed } 15 \% \text { and } 25 \% \\
\text { tariffs on } \$ 3 \text { billion worth of US } \\
\text { goods ( } 2.3 \% \text { of US exports to } \\
\text { China) }\end{array}$ & First quarter 2018 \\
\hline & $\begin{array}{l}25 \% \text { on } \$ 34 \text { billion worth of Chinese } \\
\text { goods ( } 7 \% \text { of Chinese exports to the } \\
\text { US) }\end{array}$ & $\begin{array}{l}25 \% \text { on } \$ 34 \text { billion worth of US } \\
\text { goods ( } 26 \% \text { of US exports to } \\
\text { China) }\end{array}$ & 6 July 2018 \\
\hline & $\begin{array}{l}25 \% \text { on } \$ 16 \text { billion worth of Chinese } \\
\text { goods ( } 3 \% \text { of Chinese exports to the } \\
\text { US) }\end{array}$ & $\begin{array}{l}25 \% \text { on } \$ 16 \text { billion worth of US } \\
\text { goods }(12.3 \% \text { of US exports to } \\
\text { China) }\end{array}$ & 23 Aug. 2018 \\
\hline & $\begin{array}{l}10 \% \text { on } \$ 200 \text { billion worth of } \\
\text { Chinese goods raised to } 25 \% \text { in } 2019 \\
\text { ( } 40 \% \text { of Chinese exports to the US) }\end{array}$ & $\begin{array}{l}5 \%, 10 \%, 20 \% \text { and } 25 \% \text { on } \$ 60 \\
\text { billion worth of US goods ( } 46 \% \\
\text { of US exports to China) }\end{array}$ & $\begin{array}{l}\text { Begins } 24 \text { Sep. } 2018 \text { and } \\
\text { escalates 1 June } 2019\end{array}$ \\
\hline \begin{tabular}{l|} 
Bilateral Escalation \\
Scenario (add $25 \%$ \\
tariffs on all bilateral \\
US China imports)
\end{tabular} & $\begin{array}{l}\text { US blanket tariffs of } 25 \% \text { on } 100 \% \\
\text { of Chinese exports to the US worth } \\
\$ 505.5 \text { billion (an additional } \$ 267 \\
\text { billion from previous scenario) }\end{array}$ & $\begin{array}{l}\text { Chinese blanket tariffs of } 25 \% \\
\text { on } 100 \% \text { of US exports to China } \\
\text { worth } \$ 130 \text { billion (an additional } \\
\$ 17 \text { billion added from previous } \\
\text { scenario) Chinese blanket tariffs } \\
\text { of } 25 \% \text { on } 100 \% \text { of US exports } \\
\text { to China worth } \$ 130 \text { billion (an } \\
\text { additional } \$ 17 \text { billion added from } \\
\text { previous scenario) }\end{array}$ & $\begin{array}{l}\text { Model assumed first } \\
\text { quarter 2019, but } \\
\text { delayed after second } \\
\text { quarter }\end{array}$ \\
\hline $\begin{array}{l}\text { Worst Case Scenario } \\
\text { (add } 25 \% \text { tariff on } \\
\text { all autos, parts } \\
\text { and retaliation) }\end{array}$ & $\begin{array}{l}\text { US blanket tariffs of } 25 \% \text { on all } \\
\text { imports of autos worth } \$ 350 \text { billion } \\
\text { (14.5\% of US imports equivalent to } \\
0.44 \% \text { of global GDP }\end{array}$ & $\begin{array}{l}\text { Retaliatory measures by other } \\
\text { countries including China on all } \\
\text { their auto and auto parts imports } \\
\text { from the US worth } \$ 130 \text { billion } \\
\text { ( } 6.8 \% \text { of total US merchandise } \\
\text { exports) }\end{array}$ & $\begin{array}{l}\text { Model assumed first } \\
\text { quarter 2019, but delays } \\
\text { third quarter } 2019\end{array}$ \\
\hline
\end{tabular}

Source: Author's own adaptation based on [Abiad et al., 2018].

Given the ADB analysis, the trade conflict between the two economies will be affected negatively in all scenarios. Under the current scenario, the Chinese economy would grow lower GDP by 0.48 percent, while the bilateral escalation scenario subtracts 0.55 percent GDP. In the worst case scenario, the Chinese economic growth could be less by 1.05 percent. By contrary, the U.S. economy could be affected by the trade conflict less than the Chinese economy. It could subtract 0.12 percent, 0.08 percent, and 0.24 percent respectively. It indicates that the trade conflict can impact on the two major economies rather marginal than expected in the midterm period although its impacts on Chinese economy are much higher than on the U.S. economy (see fig. 3, 4).

Another report analyzed by the Netherlands' government research institute represents the EU's perspective on the trade conflict between the U.S. and China. Given the longer term analysis of the baseline in 2030 on the trade conflict scenarios from World Scan simulations as the CPB's global CGE model, the macroeconomic results look similar. The baseline is in 2018 
when business is as usual scenarios with no trade policy change and a trade shock with negative GDP effects due to the tariff increase start in 2019. The four scenarios are unilateral steel and aluminum tariffs by the U.S., scenario 1 plus retaliatory tariffs by China, the EU, Canada, and Mexico, scenario 2 plus US-China trade conflict, and scenario 3 plus 25 percent US tariff increase on automobiles and parts imports from the EU. In these scenarios, the impact of the trade conflict on the two major economies results also in marginal, and the U.S. economy is less vulnerable than the Chinese economy. The scenario 4 subtracts the former with -0.3 percent and the latter with -1.3 percent (Bollen, Rojas-Romagosa, 2018, table 3].

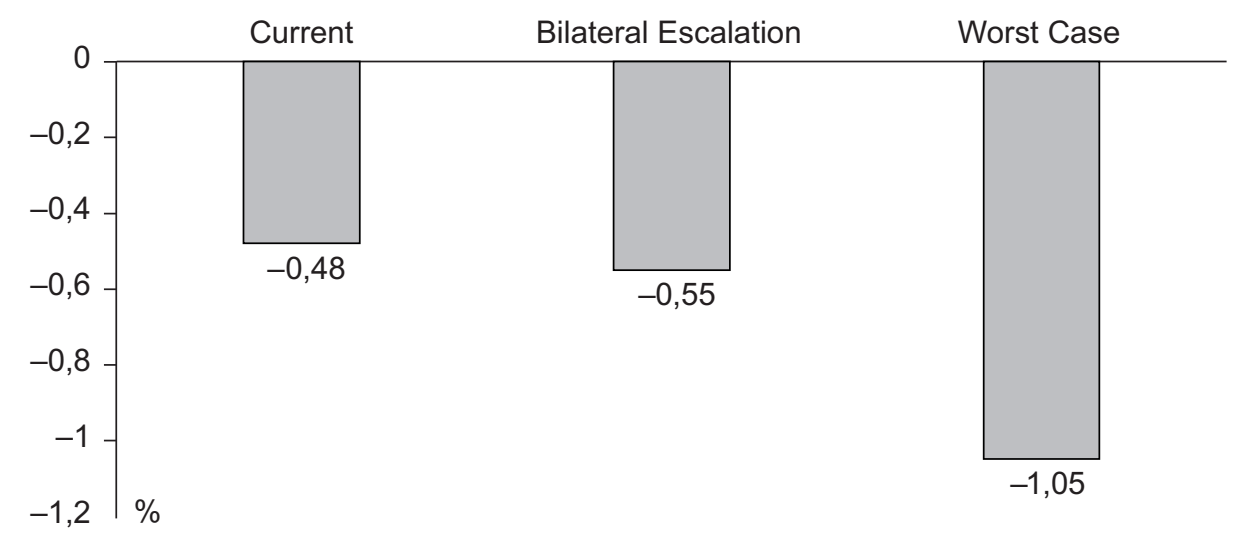

Direct, indirect, and trade redirection effects

Fig. 3. Impact of the Trade Conflict on Chinese GDP by Scenarios

Source: [Abiad et al., 2018].

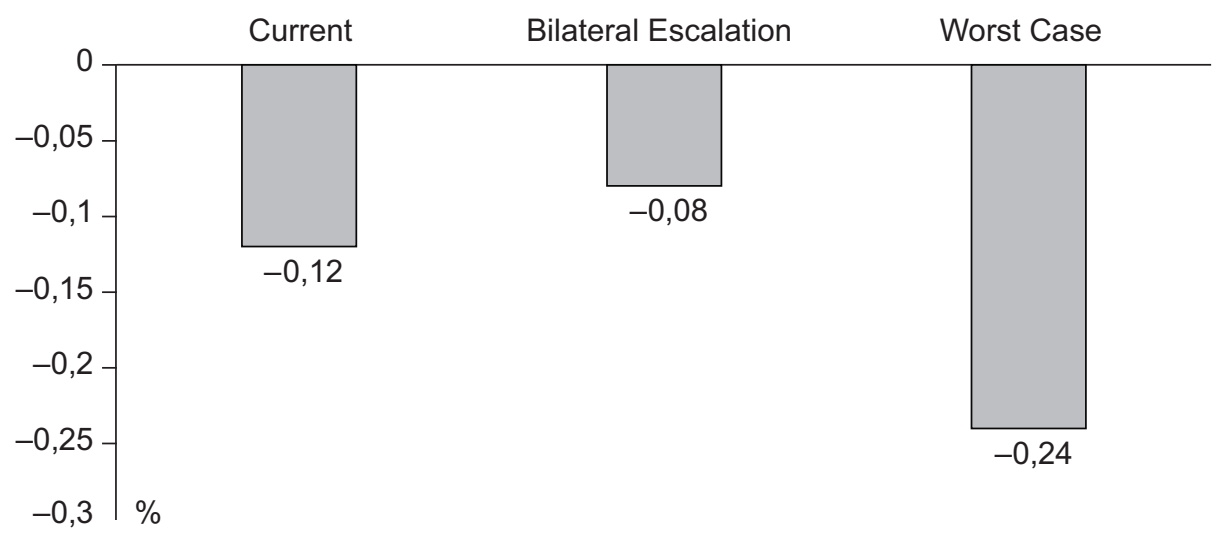

Direct, indirect, and trade redirection effects

Fig. 4. Impact of the Trade Conflict on the U.S. GDP by Scenarios

Source: [Abiad et al., 2018].

Besides these four scenarios, there is scenario for trade conflict escalation between the U.S. and all OECD member nations including trade conflict escalation between the U.S. and China. In the scenario, the impact of the trade conflict on the two major economies could be 
rather strong. It could subtract the U.S. economic growth with slightly over three percent, while the Chinese economy could generate over four percent economic growth loss [Bollen, RojasRomagosa, 2018].

Table 3. Macroeconomic Effects of the U.S. and China Compared to the Baseline in 2030

\begin{tabular}{|l|c|c|}
\hline \multicolumn{1}{|c|}{ Scenarios } & The U.S. & China \\
\hline Scenario 1 & & 0.0 \\
\hline GDP (\%) & 0.0 & 0.0 \\
\hline Export volume (\%) & -1.6 & 0.0 \\
\hline Import volume (\%) & -1.0 & 0.2 \\
\hline Scenario 2 & -0.4 & -0.9 \\
\hline GDP (\%) & -6.3 & -0.9 \\
\hline Export volume (\%) & -4.8 & -1.2 \\
\hline Import volume (\%) & & -8.2 \\
\hline Scenario 3 & -0.3 & -8.4 \\
\hline GDP (\%) & -13.5 & \\
\hline Export volume (\%) & -10.5 & -1.3 \\
\hline Import volume (\%) & & -8.3 \\
\hline Scenario 4 & -0.3 & -8.4 \\
\hline GDP (\%) & -14.0 & \\
\hline Export volume (\%) & -10.9 & \\
\hline Import volume (\%) & & \\
\hline
\end{tabular}

Source: [Bollen, Rojas-Romagosa, 2018] based on World Scan simulations.

\section{Impacts on the World Economy}

Given the ADB analysis, the trade conflict between the two economies will be affected negatively in all scenarios even in the world economy although it will affect to the world economy less than to the U.S. and Chinese economies. Under the current scenario, the global economy would grow lower GDP by 0.08 percent, while the bilateral escalation scenario subtracts 0.07 percent GDP. In the worst case scenario, the world economic growth could be less by 0.25 percent. It shows that the trade conflict between the two largest economies will impact on the global economy nearly zero in the two scenarios, but affect very low in the worst case scenario in the midterm period. In the World Scan simulation, the impact of the trade conflict on the world economy could be from -0.1 percent negative economic growth to 0.1 percent economic growth in all scenarios [Abiad et al., 2018; Bollen, Rojas-Romagosa, 2018, fig. 5, 6].

Although the world economic growth ranges from -0.1 percent to 0.1 percent based on the World Scan simulation, some part of the world could be affected more negatively than other part of the world. East Asian countries supplying intermediate goods to China and exporting final products to the U.S. and the EU could be affected mostly negative. These nations are Korea, Japan, Singapore and Taiwan. Additionally, Australia, Indonesia, Thailand, and the Philippines exporting raw materials and industrial parts to China will be impacted negatively [Bollen, Rojas-Romagosa, 2018; IMF, 2019]. 


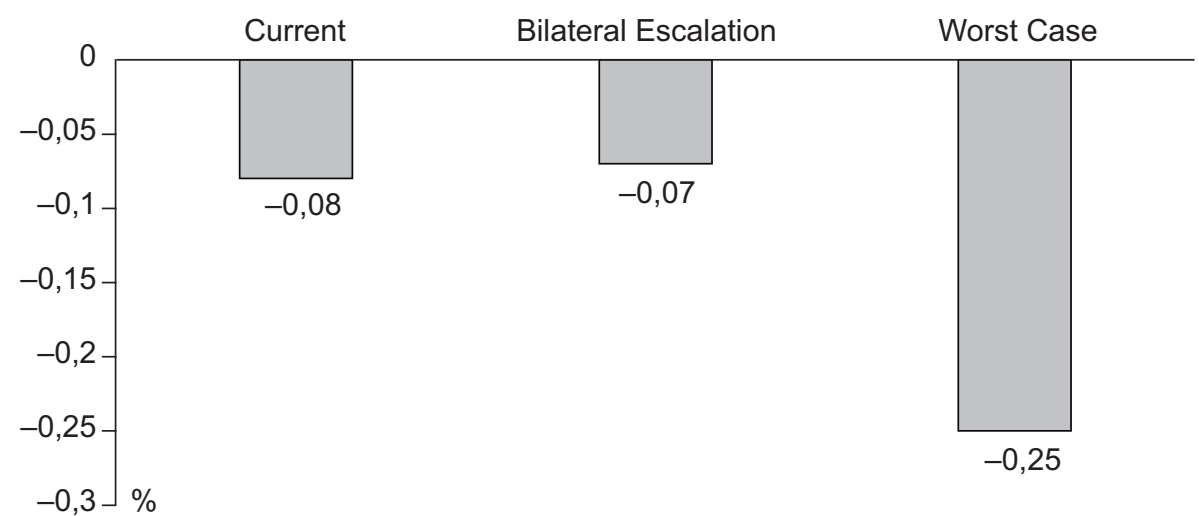

Direct, indirect, and trade redirection effects

Fig. 5. Impact of the Trade Conflict on the World GDP by Scenarios

Source: [Abiad et al., 2018].

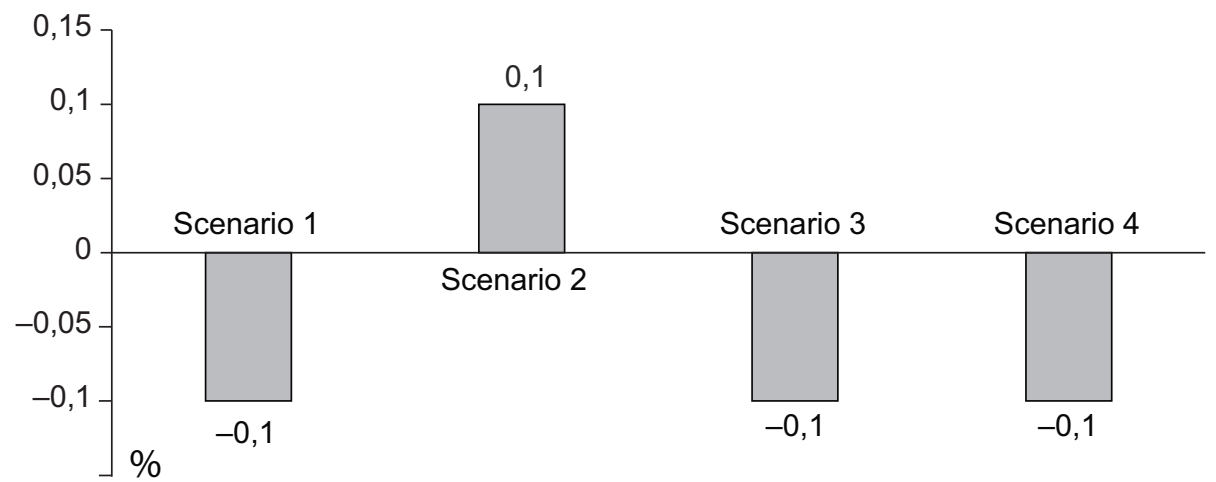

Fig. 6. Macroeconomic Effects of the World Economy Compared to the Baseline in 2030

Source: [Bollen, Rojas-Romagosa, 2018] based on World Scan simulations.

\section{Conclusion}

Trade conflict has always existed in the global economy that is rather common because some trading partners gain more benefit than others. In the economic history, our lesson is that there is no winner from the trade conflict if it is not solved by dialogue and trade agreements. We have already experienced the Great Depression in 1929/1930 that resulted in the Second World War and the total destruction of the world economy. Unfortunately, we are again experiencing severe trade conflicts between the two largest economies in the $21^{\text {st }}$ century that may impact on the global economy negatively if it continues without any proper solution.

First of all, ironically the trade conflict started from the U.S. pursuing trade protectionism particularly in the Trump Administration having various internal problems such as trade imbalance with its trading partners, income inequality, a vast government budget deficit etc. The U.S. government imposed high tariffs on imports of solar panel and washing machine first and later steel and aluminum from imports of its trading partners. After revising KORUS FTA and NAFTA, the U.S. government focuses on the trade dispute with China that is still ongoing 
process threatening to impose 25 percent tariff on all import goods from China and vice versa. Furthermore, the U.S. government plans to impose 25 percent tariff on the import of automobiles and parts from all countries although it is delayed six months long from May 2019.Fortunately, the two nations agreed the trade deal and signed on it in Jan 2020 in order to solve the trade conflict. However, it is not fully clear that the trade deal could be implemented as planned because the two parties' interests are not fully matched.

Since the severe trade conflict between the U.S. and China started in early 2018, several global and regional institutes such as IMF, ADB, European Central Bank (ECB) started to analyze the impacts of the trade conflict between the two major economies as well as the global economy. Additionally, individual nations' economic think tanks also joined this trend.For the impact of the trade conflict between G2 on their national economies and the global economy in the midterm period, the analysis of ADB predicted a minor economic impact on the U.S. and China in the three scenarios although impact on China could be higher than that of the U.S. Additionally, the impact of the world economy in these scenarios could be very low. It may be the reason why the two major economies are not afraid of continuing the trade conflict because the trade conflict in all scenarios could impact on their economies marginal. Based on this reason, the trade conflict between the U.S. and China may continue at least in the midterm period if the both parties are not satisfied with the final outcome of their trade negotiation.

In the longer term perspective based on the World Scan simulations, the trade conflict between the two major economies could also generate marginal impacts on the U.S. and Chinese economies, while it would affect the global economy negatively except the scenario 2 . However, the worst case is that the U.S. escalates trade conflict with all OECD member nations including the U.S. and China trade conflict escalation resulting in the impacts of high GDP loss on the U.S. and China with over three percent, and four percent respectively. Therefore, it is extremely important not only for the two major economies, but also for global economy to hinder the trade conflict from escalating and spreading out at the global level.

In fact, the trade conflict between G2 generates other issues such as technological dispute, financial conflict focusing on currency manipulation etc. In terms of the technological conflict, G2 competes with each other particularly in the $5 \mathrm{G}$ area that plays the core role in completing the Fourth Industrial Revolution. At present, China is ahead the U.S. in the area so that the U.S. government has tackled on suspending Chinese Huawei in the U.S. market due to the national security reason and asked its allies to follow the U.S. policy line. It means that the trade conflict is only a starting point for the technological supremacy and hegemonies power in the world politics and economy. Accordingly, it will spread out to other areas such as technology and finance continuously in the future.

\section{References}

Abiad A., Baris K., Bernabe J.A., Bertulfo D.J., Camingue-Romance S., Feliciano P.N., Mariasingham M.J., Mercer-Blackman V. (2018) The Impact of Trade Conflict on Developing Asia. Asian Development Bank Economics Working Paper Series, no 566, Dec., Manila: ADB.

Acemoglu D. (2009) Modern Economic Growth. Princeton, NJ: Princeton University Press.

Alvaredo F., Chancel L., Piketty T., Saez E., Zucman G. (2017) World Inequality Report 2018. Available at: https://wir2018.wid.world/files/download/wir2018-full-report-english.pdf (accessed on 22 May 2019).

Amadeo K.Y. (2019) US trade Deficit with China and Why It's So High. Available at: https://www.thebalance. com/u-s-china-trade-deficit-causes-effects-and-solutions-3306277 (accessed on 21 May 2019).

Bezlova A. (2007) China: Headed for Trade Wars with the U.S. Inter Press Service. April 27.

Bhagwati J. (2009) Does the U.S Need a New Trade Policy? Journal of Policy Modeling, vol. 31, no 4, pp. $509-514$. 
Bolt W., Mavromatis K., van Wijnbergen S. (2019) The Global Macroeconomics of Trade War: The EAGLE Model on the U.S. - China Trade Conflict. Available at: https://www.dnb.nl/binaries/wp623_tcm46-381884.pdf (accessed on 16 May 2019).

Bollen J., Rojas-Romagosa H. (2018) Trade Wars: Economic Impacts of US Tariff Increases and Retaliation: An International Perspective. CPB Background Document, Nov. Amsterdam: CPB Netherlands Bureau for Economic Policy Analysis.

Bown C.P., Kolb M. (2018) Trump's Trade War Timeline: An Up-to-date Guide. Peterson Institute for International Economics. Available at: https://piie.com/system/files/documents/trump-trade-war-timeline.pdf (accessed on 11 May 2019).

Bradford S., Greico P., Hufbauer G.C. (2006) The Payoff to America from Globalisation. The World Economy, vol. 29, no 7, pp. 893-917.

Broda C., Weinstein D.E. (2006) Globalization and the Gainsfrom Variety. The Quarterly Journal of Economics, vol. 121, no 2, pp. 541-585.

Cong W. (2019) Retaliation on American Firms Suggested After Huawei Ban. Global Times. May 17. Available at: http://www.globaltimes.cn/content/1150422.shtml (accessed on 18 May 2019).

Doffman Z. (2019) Trump signs Executive Order That Will Lead to U.S. Ban on Huawei. May 15. Available at: https://www.forbes.com/sites/zakdoffman/2019/05/15/trump-expected-to-sign-executive-order-leading-toban-on-huawei-this-week/\#497d903168d9 (accessed on 23 May 2019).

Eavis P., Rappeport A., Swanson A. (2020) What's in (and Not in) the US - China Trade Deal, The New York Times. 15 Jan. Available at: https://www.nytimes.com/2020/01/15/business/economy/china-trade-deal-text. html (accessed on 06 March 2020).

European Commission. (2019) EU - China: A Strategic Outlook. Strasbourg: EC.

Economic Report of the President (ERP). (2009) Economic Report of the President Together with the Annual Report of the Council of Economic Advisers. Washington, DC: U.S. Government Printing Office.

Feenstra R.C., Mandel B.R., Reinsdorf M.B., Slaughter M. (2009) Effects of Terms of Trade Gains and Tariff Changes on the Measurement of U.S. Productivity Growth. NBER Working Paper no 15592.

Genereux F. (2017) Protectionism: A Brake on Economic Growth. Economic Studies. 17 February. Available at: https://www.desjardins.com/ressources/pdf/pv170217-e.pdf (accessed on 09 May 2019).

Gomory R., Baumol W. (2009) Globalization: Country and Company Interests in Conflict. Journal of Policy Modeling, vol. 31, no 3, pp. 540-555.

Hanemann T. (2018) Arrested Development: Chinese FDI in the US in 1H 2018. June 19. Available at: https://rhg. com/research/arrested-development-chinese-fdi-in-the-us-in-1h-2018/ (accessed on 24 May 2019).

Hillebrand E.E., Lewer J.J., Zagardo J.T. (2010) Backtracking from Globalization. Global Economy Journal, vol. 10 , no 4 , p. 1 .

Hsieh P.L. (2009) China - United States Trade Negotiations and Disputes: The WTO and Beyond. Asian Journal of WTO and International Health Law and Policy, vol. 4, no 2, pp. 368-399.

Hufbauer G.C., Schott J.J. (2008) What Should Leaders do to Stop the Spread of Protectionism? What World Leaders Must Do to Halt the Spread of Protectionism (R. Baldwin, S. Evenett (eds.)). London: Centre for Economic Policy Research (CEPR). Available at: https://voxeu.org/sites/default/files/file/protectionism.pdf (accessed on 07 May 2019).

International Monetary Fund (IMF). (2015) IMF Executive Board Completes the 2015 Review of SDR Valuation. Press Release no 15/543. Available at: https://www.imf.org/en/news/articles/2015/09/14/01/49/pr15543 (accessed on 04 May 2019).

International Monetary Fund (IMF). (2019) World Economic Outlook: Growth Slowdown, Precarious Recovery. April. Washington, D.C.: IMF.

Jiming H. (2018) China - US Trade Conflict: Causes and Impact, 2018 CF40-PIIE Joint Report. Available at: https://piie.com/system/files/documents/ha20180611ppt.pdf (accessed on 23 May 2019). 
Kirton J. (2013) G20 Governance for a Globalized World. Farnham: Ashgate.

Krugman P.R. (1997) Increasing Returns, Monopolistic Competition, and International Trade. Journal of International Economics, vol. 9, no 4, pp. 469-479.

Krugman P.R., Obstfeld M. (2009) International Economics, Boston, MA: Pearson, Addison-Wesley.

Lewer J.J., Van den Berg H. (2007) International Trade and Economic Growth, Armonk, NY: M.E. Sharpe.

Martin M.F. (2018) What's the Difference? - Comparing U.S. and Chinese Trade Data, CRS Report, RS 22640, Washington D.C.: CRS.

Momani B. (2016) China at the IMF // Enter the Dragon: China in the International Financial System (D. Lombardi, H.-Y. Wang (eds.)). Montreal \& Kingston: McGill Queen's Press, pp. 267-288.

Ng T., Chung K. (2018) Trade Conflict between China and the United States and Its Impact on Hong Kong's Economy. Hong Kong: Research Office, Legislative Council Secretariat. Available at: https://www.legco.gov. $\mathrm{hk} /$ research-publications/english/1718in14-trade-conflict-between-china-and-the-united-states-and-itsimpact-on-hong-kongs-economy-20180717-e.pdf (accessed on 11 May 2019).

Office of the United States Trade Representative \& Department of Treasury. (2020) Economic and Trade Agreement Between the United States of America and the People's Republic of China. Available at: https://int.nyt.com/ data/documenthelper/6667-us-china-trade-deal/b8ef0d1826ca2b48f121/optimized/full.pdf (accessed on 06 March 2020).

Organization for Economic Cooperation and Development (OECD). (2014) Fact Book 2014. Paris: OECD.

O'Rourke K.H., Williamson J.G. (2001) Globalization and History: The Evolution of Nineteenth Century Atlantic Economy. Cambridge, MA: The MIT Press.

Park S.-C. (2017) Can Trade Help Overcome Economic Crisis? Implications for Northeast Asia Creating Regional FTA between Korea, China, and Japan and Mega FTAs such as RCEP and TPP. International Organizations Research Journal, vol. 12, no 2, pp. 104-128.

Park S.-C. (2018) U.S. Protectionism and Trade Imbalance between the U.S. and Northeast Asian Countries. International Organizations Research Journal, vol. 13, no 2, pp. 76-100.

Piketty T. (2014) Capital in the Twenty First Century. Cambridge, MA: Belknap Press.

Rosen H. (2008) Strengthening Trade Adjustment Assistance. Washington, D.C.: Peterson Institute for International Economics Policy Brief, PD 09-2, January.

Salama V., Mauldin W. (2019) Trump Administration Delays Decision on Car Tariffs. The Wall Street Journal. May 15.

Samuelson P. (2004) Where Ricardo and Mill Rebut and Confirm Arguments of Mainstream Economists Supporting Globalization. Journal of Economic Perspectives, vol. 18, no 3, pp. 135-146.

Schwab K. (2016) The Fourth Industrial Revolution. Geneva: World Economic Forum.

Stewart H. (2006) U.S. - China Trade War Looms. The Observer. March 26.

Strauss D. (2019) Global Economy Counts Cost of Trade Dispute. Financial Times. 10 May.

The White House. (2017) National Security Strategy of the United States of America. Washington, D.C.: The White House. Available at: https://www.whitehouse.gov/wp-content/uploads/2017/12/NSS-Final-12-18-2017-0905. pdf (accessed on 23 May 2019).

United States Census Bureau. (2019) Foreign Trade. Available at: https://www.census.gov/foreign-trade/balance/c5700.html (accessed on 21 May 2019).

US Trade Representative (USTR). (2018) USTR Finalizes Tariffs on \$200 billion of Chinese Imports in Response to China's Unfair Trade Practices. Available at: https://ustr.gov/about-us/policy-offices/press-office/pressreleases/2018/september/ustr-finalizes-tariffs-200 (accessed on 23 May 2019).

Wang Z., Wei S.-J., Zhu K.-F. (2018) Quantifying International Production Sharing at the Bilateral and Sector Levels. National Bureau of Economic Research Working Paper no 19677. Available at: https://www.nber.org/ papers/w19677.pdf (accessed on 25 May 2019.

World Bank. (2019) GINI Index, World Bank Estimate. Available at: https://data.worldbank.org/indicator/ SI.POV.GINI?locations=US (accessed on 22 May 2019). 